\title{
ACÚMULO DE CÁDMIO POR Saccharomyces cerevisiae FERMENTANDO MOSTO DE MELAÇO
}

\author{
ROSILENE NAVES DOMINGOS \\ Química
}

Orientador: Professor Titular: LUZZ GONZAGA DO PRADO FILHO

\begin{abstract}
Dissertação apresentada à Escola Superior de Agricultura "Luiz de Queiroz". da Universidade de São Paulo, para obtenção do título de Mestre em Agronomia, área de concentração : Microbiologia Agrícola.
\end{abstract}

PIR A C I C A B A

Estado de São Paulo - Brasil

Novembro - 1996 
Dados Internacionais de Catalogação na Publicação (CIP) DIVISĀO DE BIBLIOTECA E DOCUMENTAÇÃO - Campus "Luiz de Queiroz"/USP

\section{Domingos, Rosilene Naves}

Acúmulo de cádmio por Saccharomyces cerevisize fermentando mosto de melaço / Rosilene Naves Domingos. - - Piracicaba, 1996.

72p. : il.

Dissertaçāo (mestrado) - Escola Superior de Agricultura Luiz de Queiroz, 1997.

Bibliografia.

1. Cádmio em levedura - Concentração 2. Espectroscopia de absorção atômica 3. Fermentação alcoólica - Contaminaçāo 4. Melaço - Analise 1. Titulo 


\title{
ACÚMULO DE CÁDMIO POR Saccharomyces cerevisiae FERMENTANDO MOSTO DE MELAÇO
}

\author{
ROSILENE NAVES DOMINGOS
}

Aprovada em : 18.02 .97

Comissão julgadora:

Prof. Tit.. Luiz Gonzaga do Prado Filho

Prof. Dr. Arnaldo Antonio Rodella

Prof. Dr. Carlos Renato Corso
ESALQ/USP

ESALQ/USP

IB/UNESP/Rio Claro

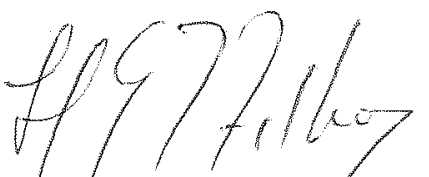

Prof. Tit. LUIZ GONZAGA DO PRADO FILHO Orientador 
A Deus e a minha mãe Abadia Naves Domingos, pela vida.

Ao meu pai, Custódio Domingos, por tudo que fez e pela falta que faz.

Aos meus familiares, nas pessoas de Dimas e Divina Naves, Otaviano e Rosa Naves, Roberto e Jesuléa Domingos, Reginaldo e Maria Helena Domingos, pela oportunidade.

A Ligia, Vitor e Denise. 


\section{AGRADECIMENTOS}

Ao Professor Titular, Luiz Gonzaga do Prado Filho, pela orientação e confiança.

Ao Conselho Nacional de Pesquisa - CNPq, pela bolsa concedida.

Ả Fundação de Amparo à Pesquisa no Estado de São Paulo - FAPESP, pelo auxilio financeiro para o desenvolvimento da pesquisa.

À Farmacêutica Bioquímica Silvana Albertini, pela colaboração e amizade.

À Professora Dra. Dejanira de Franceschi de Ângelis, do Depto. de Bioquímica e Microbiologia, IB/UNESP/Rio Claro quem me iniciou na Microbiologia.

Aos Professores do curso de pós-graduação em Microbiologia Agrícola, pelos conhecimentos transmitidos.

À Maria Estela da Silva, pela convivência e amizade.

À Assessoria Estatística do Departamento de Matemática da ESALQ/USP, na pessoa do Professor Dr. Décio Barbin pela definição da metodologia estatistica.

Ao Departamento de Ciência e Tecnologia Agroindustrial, nas pessoas dos Professores Dr. Luiz Eduardo Gutierrez, Dr. Antonio Joaquim de Oliveira, Carlos Eduardo Garcia, Professor Dr. Jorge Horii e Regina Helena Gonçalves, pelas análises da matéria-prima, nitrogênio e teor alcoólico.

Ao Professor Dr. Roberto Naves Domingos, pelas sugestões, dedicação e exemplo.

Ao Químico Reginaldo Naves Domingos, pelo auxílio na revisão e exemplo.

A Bibliotecária, Beatriz Helena Giongo, pela atenção dispensada na revisão bibliográfica. figuras.

Ao desenhista-projetista, Luiz Carlos Rodrigues, da ESALQ/USP, pela confecção das

Aos Professores Dr. José Silvio Govone, do Depto. de Estatística, Matemática Aplicada e Computacional e Édison Augusto Luciano, do Depto. de Física, IGCE/UNESP/Rio Claro, pela revisão na análise e interpretação dos resultados

Ao Professor Fernando Carvalho da Silva, pelo auxilio na fase final deste trabalho.

A Universidade do Tocantins, Centro Universitário de Palmas e Centro de Educação Tecnológica de Paraiso do Tocantins, pelas dispensas concedidas. 


\section{SUMÁRIO}

LISTA DE TABELAS

Página

LISTA DE FIGURAS

viii

RESUMO

ix

SUMMARY

$\mathrm{X}$

$\mathrm{xi}$

1- INTRODUÇÃO

01

2- REVISÃO DE LITERATURA

04

2.1. Melaço

04

2.2. Leveduras

13

2.3. Metal Pesado

25

3-MATERIAL E MÉTODOS

3.1. Materiais

33

3.1.1 Melaço

33

3.1.2 Mosto para fermentação, preparado a partir do melaço

33

3.1.3 Levedura

33

3.1.4 Sais de cádmio

33

3.1.5 Equipamento Experimental 34

3.2. Métodos

34

3.2.1 Planejamento estatístico do experimento

34

3.2.2 Preparo do mosto

35

3.2.3 Preparo do inóculo

36

3.2.4 Determinação da viabilidade celular 36

3.2.5 Determinação do peso úmido 36

3.2.6 Determinação da massa específica

36

3.2.7 Dosagem de cádmio 36

3.2.8 Dosagem de nitrogênio total 
4--RESULTADOS E DISCUSSÕES

4.1 Equipamento utilizado no experimento 43

4.2 Teor de cádmio na levedura $\quad 43$

4.3 Teor de álcool no vinho $\quad 46$

4.4 Viabilidade celular $\quad 48$

4.5 Peso úmido da levedura $\quad 50$

4.6 Porcentagem de proteína bruta na levedura $\quad 50$

5- CONCLUSÕES 52

6-REFERÊNCIAS BIBLIOGRÁFICAS . 53

APÊNDICE 1 -Análise de variância - concentração de cádmio

APÊNDICE 2 - Análise de variância - massa específica

APÊNDICE 3 - Análise de variância - células vivas

APÊNDICE 4 - Análise de variância - células mortas

APÊNDICE 5 - Análise de variância - viabilidade de brotos

APÊNDICE 6 - Análise de variância - \% brotamento

APÊNDICE 7- Análise de variância - peso úmido

APÊNDICE 8- Análise de variância - proteína bruta

APÊNDICE 9- Análise de variância - \% nitrogênio 
1 Composição do mel final em valores médios dos graus Bríx, \% sacarose, $\%$ açúcares redutores (AR) e cinzas, obtidos em cinco usinas em quatro diferentes épocas, safra 1975/76.

2 Composição média dos melaços das safras $65 / 80$ da indústria cubana

3 Elementos presentes no mel cubano, em quantidades porcentuais.

4 Tolerância de algumas linhagens de Saccharomyces cerevisiae ao etanol em incubação de $72 \mathrm{~h}$, em meio definido.

5 Produção e utilização de proteína microbiana em alguns Paises.

6 Concentração de cádmio $(\mathrm{mg} / \mathrm{kg})$ na levedura.

7 Massa específica nos vinhos contaminados com cloreto de cádmio.

8 Massa específica nos vinhos contaminados com acetato de cádmio.

9 Porcentagem da viabilidade celular da levedura recuperada através de centrifugação do mosto contaminado com cloreto de cádmio, após fermentação.

10 Porcentagem da viabilidade celular da levedura recuperada através da centrifugação do mosto contaminado com acetato de cádmio, após fermentação.

11 Peso úmido, em gramas, da levedura recuperada, após fermentação de mostos contaminados com sais de cádmio. .50

12 Proteína bruta, em gramas, da levedura, recuperada após fermentação de mostos contaminados com sais de cádmio. 


\section{LISTA DE FIGURAS}

Número

página

1 Diagrama do Sistema para fermentação simultânea, empregando três dornas com controle de temperatura 38

2 Diagrama do sistema experimental de fermentação denominado de mini-dorna, confeccionada em polipropileno, contendo uma serpentina com água circulando na temperatura programada

3 Esquema de fechamento/abertura de válvulas para controle de entrada $\mathrm{e}$ saída de água controle da temperatura nas mini-dornas

4 Concentração de cloreto de cádmio e acetato de cádmio $\mathrm{O}$, absorvido pela levedura durante o processo de fermentação, por $4 \mathrm{~h}$ a $30^{\circ} \mathrm{C}$ em mosto de melaço $12 \%$ ART enriquecido, quantificado por absorção atômica

5 Massas específicas obtidas no vinho da fermentação, $\mathrm{C}$ controle, $\mathrm{e}$ contaminadas com $\mathrm{CdCl}_{2} 2.1 / 2 \mathrm{H}_{2} \mathrm{O} \square \mathrm{e} \mathrm{CdC} \mathrm{C}_{6} \mathrm{O}_{4} \cdot 2 \mathrm{H}_{2} \mathrm{O}$, em mosto contendo $12 \%$ ART, durante 4 h a $30^{\circ} \mathrm{C}$ quantificados por densitometria.

FOTO 1 Dorna de fermentação.

FOTO 2 Sistema de tubulação para controle de temperatura 42 
ACÚMULO DE CÁDMIO POR Saccharomyces cerevisiae FERMENTANDO MOSTO DE MELAÇO

\author{
Autor: ROSILENE NAVES DOMINGOS \\ Orientador: Prof. Tit. LUIZ GONZAGA DO PRADO FILHO
}

RESUMO

O presente trabalho visou o estudo do acúmulo e, eventual, concentração de cádmio (Cd) por Saccharomyces cerevisiae, fermentando mosto de melaço, com contaminações controladas, em niveis sub-tóxicos do citado metal ( $\mathrm{mg} \mathrm{Cd} / \mathrm{kg}$ mosto). O cádmio foi o metal pesado escolhido devido à sua toxidez, e recente penetração no ambiente, como consequência do desenvolvimento tecnológico. Realizou-se análises do melaço quanto a determinação de Açúcares Redutores Totais (ART), Açúcares Redutores (AR), e dos elementos $\mathrm{P}, \mathrm{K}, \mathrm{Ca}, \mathrm{Mg}, \mathrm{Zn}, \mathrm{Cu}, \mathrm{Mn}, \mathrm{Fe}, \mathrm{B}$, e $\mathrm{S}$, como também, análise do cádmio, por espectrofotometria de absorção atômica. As condições de fermentação foram as reinantes na produção industrial de etanol. O mosto, não esterilizado, continha 12\% ART (p/p), pH 4,5 e nutrientes a base de nitrogênio, fósforo, potássio e magnésio. Para a contaminação controlada empregou-se dois sais de cádmio, cloreto $\left(\mathrm{CdCl}_{2} .21 / 2 \mathrm{H}_{2} \mathrm{O}\right)$ e, acetato $\left(\mathrm{CdC}_{4} \mathrm{H}_{6} \mathrm{O}_{4} .2 \mathrm{H}_{2} \mathrm{O}\right)$, com propriedades diferentes e quatro niveis de contaminações $(0,5 ; 1,0 ; 2,0 ; 5,0 \mathrm{mg} \mathrm{Cd} / \mathrm{Kg}$ mosto). A inoculação do mosto foi efetuada com fermento de panificação $(10 \% \mathrm{p} / \mathrm{p})$ Terminada a fermentação colheu-se amostras para determinação da viabilidade celular e porcentagem de fermento. $\mathrm{O}$ vinho foi centrifugado e procedeu-se às análises do mesmo e da levedura bruta. Mediu-se volume do vinho delevurado; a porcentagem de levedura; e o teor alcoólico, após destilação. Na levedura determinou-se peso úmido total; matéria seca; proteina bruta, e cádmio por espectroscopia de absorção atômica. Observou-se que em todos os niveis estudados houve acumulação de cádmio pela levedura. 


\title{
ACUMULATION OF HEAVY METAL BY Saccharomyces cerevisiae FERMENTING WORT OF MOLASSES
}

\author{
Author: ROSILENE NAVES DOMINGOS \\ Adviser: Prof. Dr. LUIZ GONZAGA DO PRADO FILHO
}

SUMMARY

The aim of this paper is to study the absorption and probable cadmium (Cd) casual concentration by Saccharomyces cerevisiae, fermenting wort of molasses, with control contamination, under toxic levels of cadmium ( $\mathrm{mg} \mathrm{Cd} / \mathrm{kg}$ must). Cadmium was chosen because of its toxicity, and recent penetration in the environment, as a consequence of the technological development. Analyses were carried out such as raw-material (molasses), total reducing sugar, reducing sugar, and elements such as $\mathrm{P}, \mathrm{K}, \mathrm{Ca}, \mathrm{Mg}, \mathrm{Zn}, \mathrm{Cu}, \mathrm{Mn}, \mathrm{Fe}, \mathrm{B}$ and $\mathrm{S}$ as well as the heavy metal analysis. Fermentation conditions were the same ones for alcohol industrial production. Non-sterelized wort showed $12 \%$ of total reducing sugar $(\mathrm{w} / \mathrm{w}), \mathrm{pH} 4,5$ and nutrients of nitrogen, phosphorus, kalium and magnesium. For the control contamination, two salts of cadmium were applied, chloride $\left(\mathrm{CdCl}_{2} 2.1 / 2 \mathrm{H}_{2} \mathrm{O}\right)$ and acetate $\left(\mathrm{CdC}_{4} \mathrm{H}_{6} \mathrm{O}_{4} 2 \mathrm{H}_{2} \mathrm{O}\right)$, with different properties and four levels of contamination: 0,$5 ; 1,0 ; 2,0$ and $5,0 \mathrm{mg} \mathrm{Cd} / \mathrm{kg}$ wort. The inoculation of wort was carried out with bread yeast $(10 \% \mathrm{w} / \mathrm{w})$. After fermentation, samples were selected to evaluate cellular viability and yeast percentage. Wine was centrifuged and analyses of wine without yeast and raw yeast were performed. The wine volume with out yeast, was measured in a beaker, the yeast percentage in a centrifuge and the alcohol content in a digital densimeter after distilation. An analytical balance was used to determine the total humid weight for the yeast material. Raw protein by the micro-kjeldahl method and heavy metal by atomic absorption spectroscopy. Watch all level studed haved acumulation of cadmium at yeast. 


\section{1 - INTRODUÇÃo}

A presença de metais pesados no meio ambiente é um ponto que tem atraido a atenção dos estudiosos da matéria, em função do risco que representam para os ecossistemas por eles contaminados.

Dentre os metais pesados, o cádmio $(\mathrm{Cd})$, juntamente com o chumbo $(\mathrm{Pb})$ e o mercúrio $(\mathrm{Hg})$, são os elementos que mais têm chamado a atenção dos pesquisadores devido à toxidez, e a recente penetração nos ecossistemas, como resultado do desenvolvimento tecnológico. As materiasprimas provenientes de solos fracos, que sofreram correção com adubos podem conter quantidades apreciáveis de cádmio e transportá-lo para o processo fermentativo (Babich \& Stotzky, 1983).

Estudos recentes detectaram a toxicidade do cádmio, que juntamente com chumbo e mercúrio, formam o grande trio de metais pesados, com potencial tóxico para os seres humanos e geralmente, são provenientes do ambiente. Como resultado do fenômeno da acumulação, as quantidades sub-tóxicas presentes no ambiente, podem atingir niveis de risco, nos elos finais da cadeia trófica. Esforços deverão ser concentrados, no futuro, para diminuir a poluição por cádmio, (Volesky, 1990).

As aplicações práticas do cádmio são amplas, como em pinturas por eletrodeposição, pigmentos de tintas, baterias de prata-cádmio, plásticos, etc. A produção anual de cádmio está ao redor de $20 \times 10^{3}$ toneladas. As descargas de cádmio em águas naturais são provenientes particularmente da indústria de eletrodeposição de tintas que consomem cerca de $50 \%$ do metal produzido nos Estados Unidos. Outras fontes de poluição são indústrias de baterias de niquel-cádmio e operações de fundição que são em menor número, mas são pontos de grande significância, pois podem afetar o ambiente num raio de cerca de 100 quilòmetros, (Trevors et al, 1986). 
A toxicidade do cádmio, foi constatada ser a causa da doença "Itai-Itai" no Japão, e está relacionada com problemas ósseos, causando fraturas múltiplas. O cádmio tende a se acumular no corpo humano, ao redor de $30 \mathrm{mg}$ em média no homem americano ( $33 \%$ nos rins e $44 \%$ no figado). O envenenamento crônico do cádmio produz proteinuria e causa a formação de cálculos renais. O problema de cádmio em seres humanos aparece porque a excreção é mínima, em relação ao que é absorvido, portanto o elemento tem efeito acumulativo (Volesk, 1990).

A biomassa microbiana pode sequestrar metais em diferentes partes da célula por complexação, quelação, troca de ions, coordenação, adsorção e microprecipitação inorgânica. Pode apresentar alta afinidade para metais, e absorvê-los quando presentes desde $10 \mathrm{mg} / \mathrm{kg}$. Além disso a biomassa pode ser regenerada, mediante tratamentos especificos.

A parede celular representa uma barreira protetora, particularmente pronunciada para ions metálicos, com a qual interagem, devido às suas caracteristicas aniônicas, especialmente das proteinas.

A presença de metal na célula não permite inferir de imediato que o mesmo esteja exercendo uma ação tóxica na concentração detectada, contudo, se esta célula for assimilada por outro organismo, o metal poderá ascender na escala trófica, com consequências nem sempre mensuráveis (Gadd \& Griffths, 1978).

Sabe-se que os metais pesados interferem no metabolismo das leveduras, afetando seu crescimento e a fermentação, como no caso do cádmio (Drews et al, 1953).

Quando a matéria-prima utilizada na produção de álcool é o melaço, os contaminantes presentes podem interferir no desempenho fermentativo, ou serem acumulados nas células.

O processo de fermentação normalmente utilizado no Brasil é o chamado MelleBoinot, onde as células de leveduras são recuperadas através de total recirculação das mesmas, mantendo 
a concentração celular elevada, e assim, obtendo-se um aumento no rendimento alcoólico, através do consumo menor de açúcar (Lopes, 1989). Entretanto, várias usinas e destilarias, desviam parte do leite de levedura a ser recirculado, não comprometendo a produção de etanol. Assim, a remoção de até $15 \%$ o fermento do vinho ou, $10 \%$ do leite de levedura são alguns dos níveis de "sangria" utilizados em destilarias brasileiras (Lima, 1983).

Os microrganismos possuem a capacidade de acumular metal pesado do meio de crescimento, sendo que Saccharomyces cerevisiae não é exceção. A levedura crescendo em meio com concentrações sub-tóxicas aceitáveis de quaisquer metais, poderá apresentar, devido à essa propriedade, níveis maiores que aqueles presentes no meio de crescimento, podendo assim, atingir padrões não admissiveis pela legislação vigente, o que a invalidaria como ingrediente de ração e, muito mais utilizada como suplemento protëico humano (Babichi \& Stotzky, 1983).

Essa propriedade, de acumular metais pesados, abre possibilidades de estudo em condições tão variadas, quanto são os substratos capazes de suportar o crescimento desses microrganismos.

A acumulação de metal por um microrganismo, se for por via passiva - adsorção e/ou complexação- é denominada biosorção, se, contudo, a acumulação depender da atividade metabólica do microrganismo teremos uma bioacumulação (Volesky, 1990).

O presente trabalho teve por objetivo, estudar o acúmulo de cádmio, por Saccharomyces cerevisiae, fermentando mosto de melaço, com contaminações controladas, em níveis sub-tóxicos de 0,$5 ; 1,0 ; 2,0$ e $5,0 \mathrm{mg} \mathrm{Cd} / \mathrm{kg}$ mosto. Com essa finalidade foi projetado e construído equipamento experimental, constituido de três fermentadores de $0,5 \mathrm{~kg}$ de capacidade útil cada, com controle de temperatura individual e, independente para cada fermentador. 


\section{2 - REVISÃO DE LITERATURA}

\section{1- Melaço}

A industrialização da cana-de-açúcar processa-se hoje em dois principais tipos de indústrias: usinas de açúcar e as destilarias autônomas.

As destilarias autônomas utilizam diretamente o caldo de cana que pode sofrer tratamento para ser clarificado ou não.

As usinas de açúcar têm estruturas mais complexa e empregam sempre o caldo já clarificado, frequentemente pela técnica de aquecimento, calagem e sulfitação. A seguir o caldo é concentrado até a formação de um mel denso e cor âmbar, onde ocorre a cristalização da sacarose. Nesta etapa os cristais de açúcar estão envolvidos por uma camada do mel que é separado mediante uma etapa de centrifugação, onde recupera-se, por um lado, a sacarose, e por outro o mel residual, mais conhecido como melaço.

O melaço juntamennte com o bagaço são dois importantes resíduos de fabricação do açúcar de cana. O bagaço é considerado um sub-produto por ser utilizado na geração de energia da usina ou de outras indústrias. Por ser um material em grande parte formada de polímeros de açúcares, o melaço representa uma opção potencial para produção de etanol, para a qual existem muitas opções de emprego dos materiais fermentesciveis

Segundo Furletti (1987), entre as matérias açucaradas costuma-se distinguir as diretamente fermentesciveis e as não diretamente fermentesciveis. As primeiras são os monossacarideos 
presentes nas frutas, que são geralmente utilizadas para produção do álcool das bebidas. As matérias não diretamente fermentesciveis são os dissacarídeos, que passam antes para processos de simplificação molecular que se realiza normalmente por ação de enzimas do próprio agente de fermentação, como ocorre em grande parte no melaço.

A sacarose em presença de Saccharomyces cerevisiae, desdobra-se em açúcares diretamente fermentesciveis, em uma reação denominada inversão.

$\begin{array}{llll}\mathrm{C}_{12} \mathrm{H}_{22} \mathrm{O}_{11}+\mathrm{H}_{2} \mathrm{O} \longrightarrow & \mathrm{C}_{6} \mathrm{H}_{12} \mathrm{O}_{6} & \text { Saccharomyces cerevisiae } \\ \text { sacarose } & \text { glicose } & \text { frutose }\end{array}$

A enzima responsável por esta reação denomina-se $\beta$-d-frutofuranosidase, que é sintetizada e excretada pela própria levedura.

Os grãos de cereais, as raízes e tubérculos, castanhas (babaçú), possuem polissacarídeos e portanto esses materiais só fermentam depois de sacarificados. Esta sacarificação pode ser feita via enzimática ou por meio de ácidos

$\left(\mathrm{C}_{6} \mathrm{H}_{10} \mathrm{O}_{5}\right)_{\mathrm{n}}$

amido
$\mathrm{H}$

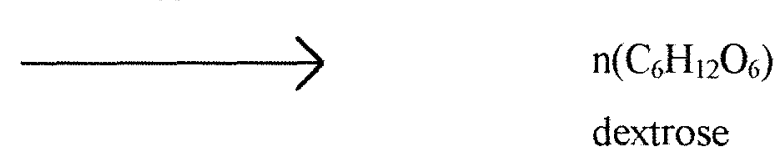

Gasparini-Barbosa (1995) descreveu o aproveitamento de residuos lignocelulósicos, objetivando a hidrólise do bagaço de cana para obtenção de monossacarideos fermentesciveis 


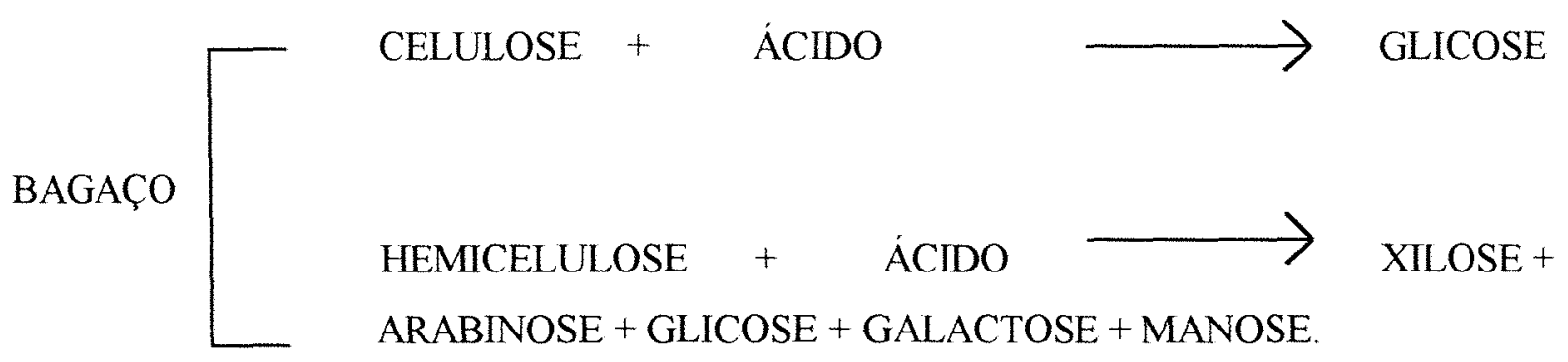

O melaço pela sua composição química, rica em açúcares, e outros componentes orgânicos e minerais, constitui um importante substrato do metabolismo microbiano, para obtenção de substâncias químicas, como solventes, ácidos orgânicos, vitaminas, antibióticos, aminoácidos, proteina microbiana, lipídeos, ácidos nucleicos, esteróis e enzimas (Lima, 1975).

Dentre essas possibilidades de utilização do melaço via metabolismo microbiano, destaca-se a produção de etanol, como fonte alternativa de energia. Neste sentido, o Brasil implantou o PRÓÁLCOOL, maior projeto de biotecnologia, empregando microrganismos, de que se tem notícia.

Olbrich (1960), publicou análises dos açúcares do melaço que consistem predominantemente de sacarose, mas, também, de açúcar invertido e cestose. Os produtos de inversão glicose e frutose - não significam apenas perda de sacarose, mas perda de qualidade, pois em parte, nas condições da fabricação do açúcar, transformam-se em ácidos e substâncias coradas. Como produto de decomposição da frutose em meio alcalino formam-se, principalmente, ácido láctico, furfurol, oximetilfurfurol, ácido trioxiglutárico, ácido trioxibutírico, ácido fórmico, ácido acético e gás carbônico. Pode ainda formar produtos de oxidação, pela entrada de ar nos recipientes de estocagem.

O melaço apresenta uma composição bastante variável (Serra et al, 1982). Estes autores publicaram os resultados de análises do mel final obtidos na safra açucareira de 1975/76, em quatro épocas de cinco usinas da região central do Estado de São Paulo (Jaú), os quais são mostrados na Tabela 1 . 
Vários são os fatores que influenciam na composição do melaço (COPERSUCAR, 1987). Destacam-se entre eles a natureza e qualidade da cana processada, método de fabricação do açúcar, o sistema e tempo de armazenamento, bem como as regiões geográficas de onde provêm.

Tabela 1 - Composição do mel final em valores médios dos graus Bríx, \% sacarose, \% açúcares redutores (AR) e cinzas, obtidos em cinco usinas em quatro diferentes épocas, safra $1975 / 76$.

\begin{tabular}{ccccc}
\hline ÉPOCA & ${ }^{\circ}$ BRIX & SACAROSE $(\%)$ & AR (\%) & CINZAS (\%) \\
\hline 1 & 90,85 & 39,87 & 51,5 & 8,04 \\
2 & 91,42 & 38,59 & 49,7 & 8,31 \\
3 & 91,53 & 39,27 & 50,7 & 7,96 \\
4 & 89,66 & 38,72 & 51,1 & 7,83 \\
\hline $\bar{X}$ & 90,87 & 39,11 & 50,8 & 8,04 \\
\hline
\end{tabular}

Fonte: Adaptado de Serra et al (1982).

Estão representados na Tabela 2, dados sobre a composição química do melaço, resultante de estudos realizados em Cuba, quanto aos açúcares, substâncias orgânicas e inorgânicas (compostos nitrogenados, ácidos voláteis e outros componentes). 
Tabela 2 - Composição média dos melaços das safras 65/80 da indústria cubana.

\begin{tabular}{cc}
\hline CONSTITUINTES & MÉDIAS (\%) \\
\hline Água & 15,96 \\
Sacarose & 35,53 \\
Glicose & 9,90 \\
Frutose & 10,04 \\
Redutores infermentesciveis & 4,01 \\
Cinzas & 9,57 \\
Substâncias gomosas e colóides & 8,06 \\
Cloretos & 1,25 \\
Outros & 5,68 \\
\hline
\end{tabular}

Fonte: ICIDCA, 1986

O melaço cubano apresenta-se mais pobre em açúcares e mais rico em cinzas que a média geral dos melaços brasileiros.

A análise efetuada em melaço pelo Instituto Cubano de Los Derivados de La Canã de Azúcar (ICIDICA, 1986), indicaram a presença dos seguintes grupos de substâncias além dos açúcares fermentesciveis: 


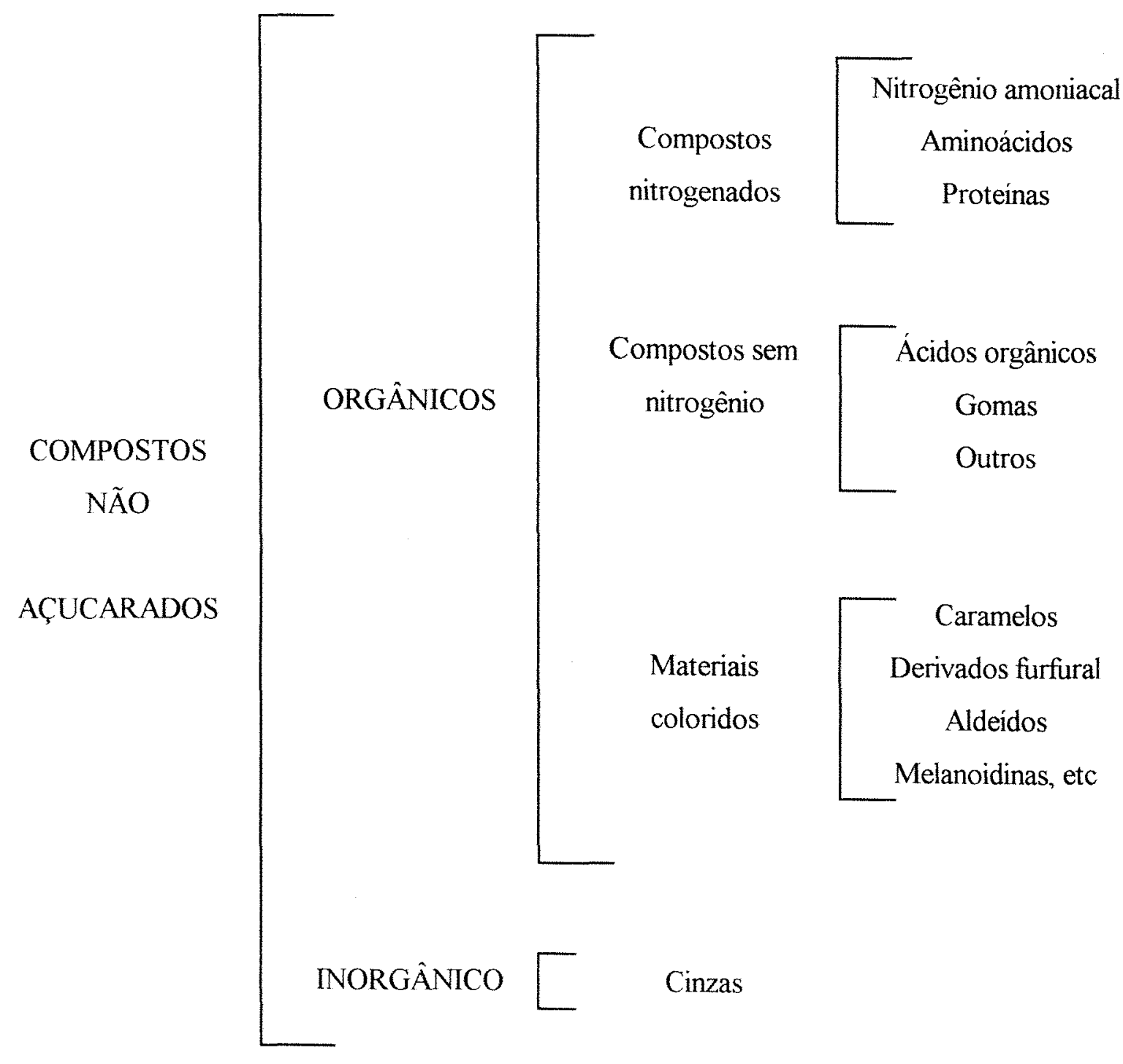

Outras substâncias detectadas no melaço pelo ICIDCA, são: aminoácidos, destacando-se o ácido aspártico e glutâmico, vitaminas B-1, B-2 e B-6, e ácido pantotênico, ácidos aconítico, láctico e fórmico, acético, propiònico, butírico e isobutírico, graxos, láurico, mirístico, palmítico, esteárico, oleico, linolênico e linoleico.

Ainda segundo esta publicação, a cor do melaço se deve aos tratamentos térmicos do caldo, que se por um lado eliminam substâncias como proteinas, gomas e colóides, por outro 
promovem a decomposição alcalina, que representa de 60 a $70 \%$ de todo produto colorido do melaço. A formação de produtos coloridos no caldo de cana tem como base fundamental os açúcares redutores (AR). O aumento na concentração dos AR do caldo na proporção de 0,13 a $0,2 \mathrm{~g} / 100 \mathrm{~g}$ de sacarose, até 0,24 a $0,38 \mathrm{~g}$ provoca uma modificação na tonalidade de cor, tornando-a mais escura em torno de $40 \%$, comparando-se com a cor inicial. As soluções alcalinas sobre AR induzem a formação do ion 1,2 endiolato, com adição ou perda de prótons. A temperatura também interfere sobre a glicose levando a formação de pequenas quantidades de hidroximetilfurfural, de cor âmbar.

Dos melaços, frequentemente pode-se separar duas frações coloridas: uma preta $\mathrm{e}$ outra amarela. $\mathrm{Na}$ fração preta encontram-se produtos de condensação aldólica, enquanto que na fração amarela encontram-se ácido lactônico, cinzas e resíduos de aminoácidos.

Os caramelos e as melanoidinas surgem como resultado da decomposição térmica da sacarose. A cor do melaço varia do amarelo até o avermelhado. As análises realizadas no melaço indicam uma certa relação da cor com o fenômeno da auto-destruição.

O melaço, devido a sua composição orgânica e inorgânica, possue um grande poder tampão, oferecendo uma resistência amortecedora à alteração de pH. Esta ação é auxiliada pela presença de sais, ácidos orgânicos, bases fracas e seus sais.

$\mathrm{O}$ poder tamponante do melaço tem especial interesse nos processos fermentativos de produção de etanol e de levedura. Dentre os elementos que compõem os sais de melaço, destacam-se aqueles citados na Tabela 3, além de traços dos seguintes elementos: $\mathrm{Pb}, \mathrm{Ni}, \mathrm{Mo}, \mathrm{Va}, \mathrm{Ag}, \mathrm{Ti}$, $\mathrm{Co}, \mathrm{Zn}, \mathrm{Ba}$ e $\mathrm{Sn}$. 
Tabela 3 - Elementos presentes no mel cubano, em quantidades porcentuais.

\begin{tabular}{cc|cc}
\hline ELEMENTOS & MEL \% & ELEMENTOS & MEL \% \\
\hline $\mathrm{K}$ & 2,54 & $\mathrm{P}_{2} \mathrm{O}_{5}$ & 0,123 \\
$\mathrm{SO}_{3}$ & 1,43 & $\mathrm{Si}$ & 0,180 \\
$\mathrm{Cl}$ & 1,25 & $\mathrm{Mn}$ & 0,007 \\
$\mathrm{Ca}$ & 1,23 & $\mathrm{Fe}$ & 0,017 \\
$\mathrm{Mg}$ & 0,50 & $\mathrm{Cu}$ & 0,0016 \\
$\mathrm{Na}$ & 0,18 & $\mathrm{Al}$ & 0,008 \\
\hline
\end{tabular}

Fonte: ICIDCA, 1986

O melaço, sendo rico em substâncias orgânicas, sob efeito de esterilização a quente, sofre alterações, diminuindo o $\mathrm{pH}$ devido principalmente a formação de ácidos, pela decomposição da sacarose.

Outro aspecto que deve ser cuidado, quanto a qualidade do melaço, refere-se ao conteúdo dos microrganismos presentes. Estes são introduzidos através do caldo, com impurezas de restos culturais e solo, os quais trabalhados juntamente com os colmos na extração, atingem cifras de vários milhões de muitas espécies de microrganismos que persistem através do processo ou são incorporados pelas próprias condições ambientais. Sendo os mais comuns bacilos, micrococos, diplococos, além de leveduras pertencentes a gêneros que não são Saccharomyces (Olbrich, 1960).

Nos melaços cubanos (ICIDICA, 1986), os microrganismos, mesófilos e termófilos, estão presentes entre $1,5 \times 10^{2}$ e $1,7 \times 10^{4}$, do qual foram isolados as seguintes espécies: Bacillus subtilis (Ehienberg) Cohn, B. licheniformis (Weigmann) Chester, B brevis Migula, B. cereus Frankland y Frankland, B. megaterium de Bary, B. pumilus Meyer y Gottheil, Brevibacterium imperiale (Steinhaus) Breed, Schizossaccharomyces pombe Linder, S. octosporus, Saccharomyces rouxii Boutroux, S. mellis (Fabian et (uinet) Lodder et Kreiger Van Rij, Rhodotorula mucilaginosa (Jörgensen) Harrison, Candida tropicalis (Cast.) Berkhout. 
Outras espécies microbianas encontradas esporadicamente, no melaço, são: Micrococcus varians Migula, M. luteus (Schroeter) Cohn, M. caseolyticus Evans, M. candidus Cohn, Sarcina hansenii (Miquel) Breed, Sarcina flava de Bary, e Microbacterium lacticum orla-Jensen.

Hernandez (1995), afirma que o melaço pode ser armazenado por um tempo razoável sem sofrer deterioração. Porém apesar de sua alta concentração, eventualmente pode contaminar-se com microrganismos, principalmente os osmofilicos. As principais ações dos contaminantes no melaço são de provocar a inversão da sacarose e consumir os açúcares, sendo responsáveis pelo aparecimento de várias substâncias orgânicas que podem, posteriormente, prejudicar o desenvolvimento dos microrganismos que nele terão que crescer.

No Brasil, a maior parte do melaço é utilizado na fabricação de álcool, parte é exportado. De acordo com a proveniência, pode-se ter mel de primeira, mel de segunda e mel residual ou esgotado. Este produto é obtido nas usinas em proporções muito variáveis segundo o excesso de cana e outros fatores. Admite-se comumente uma produção de melaço de 25 a 40 litros por tonelada de cana consumida na indústria, mas esta proporção pode atingir 50 a 60 litros devido a fenômenos de estiagem, geada e outros (Lima, 1975).

O padrão para exportação é $85^{\circ}$ Brix , feito com diluição $1: 1$, isto corresponde a aproximadamente $82^{\circ}$ Bríx refratométrico. O mel final nesta concentração não está sujeito a atividade microbiana, exceto na superficie. Entretanto pode ocorrer decomposição se a temperatura ultrapassar o limite de $45^{\circ} \mathrm{C}$. A evidência indica que a reação de partida, para a alta decomposição do melaço, é uma reação química que ocorre entre os AR e aminoácidos, tal reação é exotérmica e libera gás carbônico em baixas temperaturas, a reação ocorre lentamente com pequena produção de gás carbônico. $\mathrm{O}$ aumento da temperatura implica na evolução acentuada de gás carbônico, causa elevação no volume do melaço e formação de espumas. No periodo de estocagem deve haver um procedimento para homogenização, para evitar a formação de pontos quentes. O melaço estocado a $25^{\circ} \mathrm{C}$ muda muito pouco a composição, por vários anos, (Payne, 1989). 


\section{2 - Leveduras}

O emprego de alimentos fermentados é o mais antigo processo microbiano registrado em informações de culturas babilônicas, egipcias e hebráicas.

Segundo Hobson (1987), citado por Halász \& Lasztity (1991), o primeiro registro do uso de levedura é relativo a obtenção de uma espécie de cerveja ácida, chamada "BOOZAH", conhecida a $6000 \mathrm{AC}$, no Egito.

Sabe-se que pelo menos no inicio da Era Cristã, o uso de vinhos e pães já era de costume muito difundido. Contudo o conhecimento dos agentes responsáveis por este processo só pode ser ampliado a partir da invenção do microscópio no século XVII, por Antonie Van Leeuwenhoek. Contudo foi o trabalho de Louis Pasteur, publicado em seu "ÉTUDES SUR VIN" em 1866, que estabeleceu o papel da levedura na transformação do açúcar em álcool, e que a levedura é um organismo vivo (Halász \& Lásztity, 1991).

A partir do conhecimento da existência de leveduras, estas passaram a ser conhecidas por diferentes nomes, "Levure" na França, "Hefe" na Alemanha, "Zestos", na Grécia, "Yeast", na Inglaterra (Phaff et al, 1978). No Brasil é conhecida como fermento ou levedura e corresponde a um grupo heterogêneo de células eucarióticas, de forma predominantemente unicelular, embora algumas espécies formam pseudomicélios, outras são de formas muito aberrantes (Lodder, 1971).

As leveduras para sua multiplicação e metabolismo dependem de carbono na forma orgânica e assumem elevada preferência pelos carboidratos, especialmente os monossacarideos.

A morfologia do grupo é bastante variada e, as células ao se multiplicarem, dependendo das condições nutricionais, assumem formas que podem confundir os analistas. Diante disso, Lodder (1971), propôs que o exame morfológico das células, para sua identificação seja efetuado em 
condições padronizadas tendo o meio sólido de agar-malte, e o meio líquido de extrato de malte como referências.

Trabalhos de Lodder (1971), trazem a descrição de 350 espécies de leveduras, contudo, posteriormente foram descritas por Kreger VanRij, mais de 100 novas espécies. As espécies de leveduras, até então conhecidas, foram agnupadas em 66 gêneros (Barnett et al, 1986), porém, Barnett (1992) afirma que apenas 10 espécies do gênero Saccharomyces são aceitas pela "Yeast Division of the Centraalbureau voor Schimmelcultures", como pertencentes à este gênero. São elas: $S$. bayanus, $S$. castellii, S. cerevisiae, S. dairensis, S. exiguus, S. khuyveri, S. paradoxus, S. pastoriamus, S. servazzii, S. unisporus.

Das espécies taxonomicamente conhecidas, relativamente poucas são utilizadas industrialmente para a produção de biomassa, óleo, vitaminas, enzimas, solventes, ácidos orgânicos, ácidos nucleicos, proteínas, etc.

As leveduras são empregadas, com alta frequência na obtenção de produtos de consumo diário, dentre eles o pão e as bebidas alcoólicas, destacando-se as fermentadas e aquelas posteriormente destiladas. Caracterizam-se por apresentarem alta resistência em condições de ambiente, $\mathrm{pH}$, presença de sais e temperatura de até aproximadamente $35^{\circ} \mathrm{C}$. Tem alta taxa de reprodução, podendo reproduzir-se sexuadamente formando esporos ou reprodução assexual envolvendo brotamento, gemulação ou fissão binária (Lodder, 1971).

As leveduras secas apresentam uma composição química aproximada de $6 \%$ de umidade, $45 \%$ de proteína ( $\mathrm{Nx} 6,25)$, 6\% de lipídeos e 9\% de cinzas. Como substâncias de reserva as leveduras acumulam trealose, glicogênio e lipídeos. Nas leveduras destacam-se os componentes de parede celular, glicana, manana e quitina, (Ângelis \&Thomazini, 1980).

A composição do meio de cultura utilizado interfere na constituição quimica da parede celular da levedura. Estudos de ultraestrutura revelam uma camada fibrilar externa, constituida de 
glicana e manana, sendo que a glicana é responsável pela rigidez da parede celular. Após vários anos de estudos e análises, constatou-se que este carboidrato é um polímero linear, com 10 a $20 \%$ de ligações $\beta(1-6)$, e as demais $\beta(1-3)$. Por outro lado, a manana é formada por ligações $\alpha(1-6), \alpha(1-2)$ e $\alpha(1-3)$ e de manoses, nas ramificações das cadeias laterais, (Phaff, 1978).

Hamada et al (1984), citado por Trindade (1987), comprovaram alterações na forma das células, quando as mesmas cresceram em condições salinas variadas, porém as propriedades químicas permaneceram.

A quitina é considerada também um polímero integrante presente em menor proporção na parede celular das leveduras, e o polimero é formado por ligações $\beta(1-4)$ de $N$ acetilglicosamina. Vários estudos confirmam que as condições de cultivo interferem no conteúdo de quitina das células, especialmente a idade e o número de cicatrizes de brotamento, local onde fica concentrado a maior proporção de quitina, que não é um constituinte obrigatório das leveduras, ex. Rhodotorulas.

Fazem parte da estrutura constitutiva das células as proteínas que estão presentes na parede, no citoplasma e no núcleo. O teor de proteína das leveduras sofre interferências quanto a idade, linhagem da cultura e nutrientes do meio onde se multiplicaram. $\mathrm{Na}$ parede celular das leveduras estão presentes proteínas, sendo evidenciado a complexação destas, constituindo as lipoproteínas e glicoproteinas (mananaproteína).

A levedura para obter energia pode executar dois tipos de metabolismos partindo de carboidratos, o oxidativo, que ocorre em presença de oxigênio: 
$\mathrm{C}_{6} \mathrm{H}_{12} \mathrm{O}_{6}+6 \mathrm{O}_{2} \longrightarrow \mathrm{CO}_{2}+6 \mathrm{H}_{2} \mathrm{O}+688 \mathrm{kcal}$, e metabolismo fermentativo, na ausência de oxigênio:

$\mathrm{C}_{6} \mathrm{H}_{12} \mathrm{O}_{6} \longrightarrow 2 \mathrm{C}_{5} \mathrm{H}_{5} \mathrm{OH}+2 \mathrm{CO}_{2}+54 \mathrm{kcal}$

A reação de fermentação pode acontecer com a célula intacta, ou em extratos livres de células. Em ambas as formas metabólicas, ocorre a degradação dos carboidratos. Este mecanismo metabólico utiliza a energia na forma de ATP, bem como gera ATP, através das vias de fosforilação do substrato ou fosforilação oxidativa.

Os metabolismos em que a atividade redutora é gerada e utilizada são: redução do piruvato e outros substratos para formar produtos finais, ou para reações biossintéticas, requerentes da ação redutora, (Moat \& Foster, 1988).

Do metabolismo anaeróbio das leveduras, resulta a produção de etanol, que na maior parte é excretado para o meio ambiente e a outra parte é retido na própria célula.

Saccharomyces cerevisiae permanece metabolicamente viável e ativa em meio contendo alta concentração de etanol $(20 \% \mathrm{v} / \mathrm{v})$. A questão da resistência tem intrigado muitos pesquisadores que verificam uma habilidade diferencial de fermentação etanólica de uma espécie para outra de leveduras e que o fenômeno está relacionado com a tolerância ao etanol produzido. Linhagem de S. cerevisiae, utilizada na produção de saké, é a levedura pesquisada mais tolerante ao etanol que se 
conhece. Contudo, a maior parte das linhagens de S. cerevisiae são capazes de tolerar uma concentração de etanol ao redor de 8 a $9 \% \mathrm{v} / \mathrm{v}$.

Rose (1980), elaborou estudos sobre a maior concentração de etanol que previne o crescimento de leveduras encubadas por 72 horas, em meio definido.

Tabela 4. Tolerância de algumas linhagens de Saccharomyces cerevisiae ao etanol em incubação de $72 \mathrm{~h}$, em meio definido.

\begin{tabular}{lcc}
\hline Linhagens & \multicolumn{2}{c}{ Concentração de etanol } \\
\cline { 2 - 3 } & $\% \mathrm{v} / \mathrm{v}$ & $\mathrm{mol} / \mathrm{l}$ \\
\hline NCYC 366 & 7,0 & 1,2 \\
NCYC 431 & 13,0 & 2,2 \\
NCYC 478 & 12,0 & 2,0 \\
NCYC 479 & 13,0 & 2,2 \\
CBS 1198 & 12,0 & 2,0 \\
\hline
\end{tabular}

Fonte: Adaptado de Rose, 1980

Pesquisas indicam que uma tolerância à glicose, induzida em Saccharomyces cerevisiae, foi acompanhada de uma diminuição da resistência ao etanol. O fenômeno de tolerância ao etanol parece estar relacionado com a presença de membranas celulares ricas em estigmasterol ou residuos de linoleil, quando comparados com células enriquecidas em campesterol ou colesterol, e resíduos de linoleil. Quando membranas foram enriquecidas com resíduos de palmoleil, a resistência ao etanol foi maior que quando as membranas tinham residuos de oleil, (Rose, 1980)

Uma característica importante das leveduras é sua xerotolerância, que é a capacidade de sobreviver em baixa atividade de água ou alta pressão osmótica. Os organismos eucariotos xerotolerantes acumulam alta concentração de poliol em resposta ao "stress" de água, sendo que em "stress" extremo, o poliol é o glicerol. 
Segundo Christian (1963), citado por Tilbury (1980), as leveduras osmofilicas são aquelas capazes de se multiplicarem em sucos concentrados, com atividade de água (aw) abaixo de $0,85 \%$, sendo que corresponde à $65^{\circ}$ Bríx de sacarose $(0,865 \mathrm{aw})$.

As leveduras osmofilicas ocorrem na natureza e passam a contaminar alguns tipos de alimentos, dentre eles os xaropes, sucos concentrados, produtos de confeitaria e padaria, derivados do leite, de frutas e de carne. As espécies mais comuns são Saccharomyces rouxii, S. bisporus, S. bailii e Torulopsis apicoli. Possuem temperatura ótima de crescimento ao redor de $27^{\circ} \mathrm{C}, \mathrm{pH}$ ótimo entre 4,0 e 4,5 , crescem em condições aeróbias ou anaeróbias facultativas e têm capacidade a frutofilia.

Durante períodos de carência alimentar a Alemanha produziu óleo com levedura partindo de resíduos açucarados.

As indústrias de alimento e de cosmético estão desde há muito aproveitando a riquesa desses microrganismos, como proteina microbiana, pois tem a grande vantagem de não ser patogênico.

Muitos outros produtos podem ser obtidos do metabolismo da levedura, entre eles destacaremos a trealose, pigmentos carotenóidicos, enzimas, vitaminas, especialmente complexo $\mathrm{B}$, esteróis, efedrina, etc.

Para aproveitamento dos outros sub-produtos metabólicos as leveduras, de uso industrial, são classificadas quanto a maneira que os mesmos são encontrados em produtos constitutivos de:

- matéria celular seca que tem constituição semelhante a todos os seres vivos e serve de suplemento alimentar;

- gorduras e macromoléculas, constituindo proteínas, enzimas e ácidos nucleicos;

- compostos extraiveis incluindo coenzimas e vitaminas; 
- produtos resultantes da quebra das moléculas, por exemplo aminoácidos formados pela hidrólise de proteínas, purinas e pirimidinas dos ácidos nucleicos;

- carotenóides;

- produto de excreção;

- compostos produzidos pela ação de enzimas em substratos específicos;

- ação de $\alpha$ e $\beta$ amilases sobre amido produzindo glicose;

- síntese da efedrina partindo do benzaldeído;

- síntese da tiamina (vitamina B1) partindo do tiazol e piramidina (Ângelis \& Thomazini, 1980).

Segundo Dziedak (1987), as leveduras estão recebendo mais atenção, por parte dos pesquisadores, devido aos beneficios nutricionais fornecidos ao homem. Sua utilização pode ser na forma de levedura seca, suplementando a alimentação humana, ou, enriquecendo os sabores de lanches, carnes e produtos derivados do leite.

As características que tornam os microrganismos interessantes, incluindo a levedura como produtores de proteína, segundo Kihlberg (1972), são:

- rápida multiplicação;

- capacidade de desenvolvimento em substrato de custo acessível;

- facilidade de obtenção;

- utilização de nutrientes em suas formas mais simples;

- produção independente de fatores ambientais e climáticos;

- formação de produto de elevado valor nutritivo.

Segundo Rose (1979), o uso de proteina microbiana, Singel Cell Protein também conhecida como "SCP", é uma realidade implantada em vários paises do Mundo. Muitas organizações estão envolvidas na produção de "SCP", em quantidade estimada como está registrado na Tabela 5. 
Tabela 5 - Produção e utilização de proteína microbiana em alguns Países.

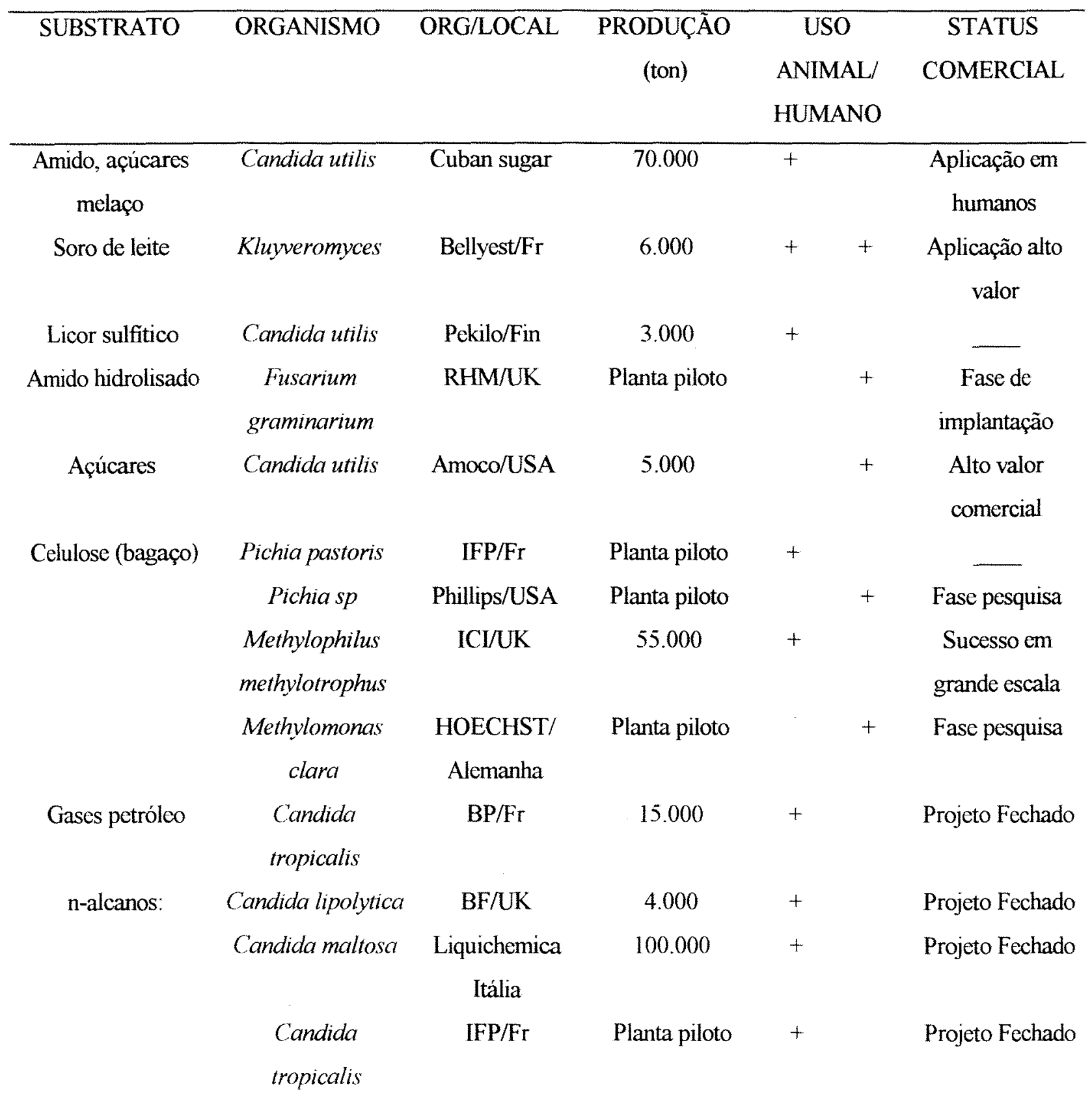

Fonte: Adaptado de Rose, 1979 
Os substratos alternativos, como gases de petróleo e metanol, exigem um controle de qualidade quanto aos residuos que permanecem na biomassa. Passar por um rigoroso controle de qualidade, por exemplo, o metanol deve estar abaixo de $4 \mathrm{mg} /$.

Os produtos "SCP" produzidos por substratos de origem natural são geralmente vistos como um suporte eficiente para o crescimento animal. Por outro lado "SCP" derivados de hidrocarbonetos requerem maiores cuidados para avaliação da sua composição e dos testes toxicológicos. O autor encerra dizendo que o maior fator que inibe o desenvolvimento de produtos "SCP" de hidrocarbonetos e materiais residuais é o próprio custo de implantação do projeto industrial (Rose, 1979).

As leveduras alimentares podem ser obtidas em condições industriais utilizando-se várias fontes de carboidratos, como melaço, licor sulfitico, malte, soro e amido hidrolizado (Halász \& Lasztity, 1991). Contêm alto teor de proteina e vitaminas do complexo B (Desmonts, 1966b), e quando secas, apresentam aproximadamente $50 \%$ de proteínas e aminoácidos em proporções adequadas. Junto com outros alimentos, as leveduras são um importante suplemento às necessidades nutricionais de indivíduos carentes (Prescott \& Dunn, 1972; Ângelis \& Thomazini, 1980).

A utilização da biomassa de levedura pode ser de desde o aproveitamento integral, ou de apenas alguns componentes, para isso, diferentes técnicas podem ser empregadas (Halász \& Lásztity, 1991). Estudos de Boucourt (1986), mostraram que as leveduras se ingeridas pelos animais, devem estar biologicamente inativas, devido a grande afinidade por açúcares e vitaminas (Desmonts, 1968). A tecnologia de produção celular microbiana em escala comercial, para alimentos e rações, foi desenvolvida neste século. Até o século passado, recuperava-se o máximo de leveduras do gênero Saccharomyces da produção de bebidas fermentadas, principalmente cervejas, utilizando-as, então, em panificação. Em 1868, Fleischmann iniciou a produção industrial da levedura prensada e, contribuiu na melhoria da bioquímica da fermentação e de técnicas de engenharia, auxiliando muito o desenvolvimento da moderna utilização de leveduras (Halász \& Láztity, 1991). 
A fabricação de levedura é um processo aeróbio e exergônico, portanto é necessário fornecer grandes volumes de ar e dispor de algum sistema de eliminação de calor para manter a temperatura adequada ao processo, aproximadamente $30 \pm 2^{\circ} \mathrm{C}$.

A equação empirica que pode representar a formação de biomassa é a seguinte:

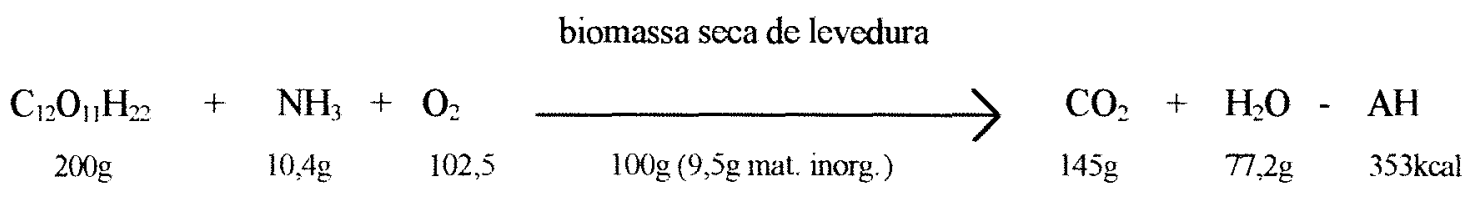

A equação molar equilibrada seria:

\begin{tabular}{|c|c|c|c|c|c|c|c|}
\hline $\mathrm{C}_{12} \mathrm{O}_{11} \mathrm{H}_{22}+$ & $\mathrm{NH}_{3}$ & + & $\mathrm{O}_{2}$ & $\mathrm{C}_{3,72} \mathrm{O}_{1,952} \mathrm{H}_{6,128} \mathrm{~N}_{0,612}$ & $\mathrm{CO}_{2}+$ & $\mathrm{H}_{2} \mathrm{O}$ & $-\mathrm{AH}$ \\
\hline 0,585 & 0,612 & & 3.203 & & 3,3 & 4,28 & $90,11 \mathrm{kcal} / \mathrm{mmO}_{2}$ \\
\hline
\end{tabular}

Contudo o balanço apresentado a respeito do balanço de conversão do açúcar em massa biológica $(50 \%)$, pode ser substancialmente afetado pelas condições em que ocorre a fermentação, bem como pela espécie de linhagem do fermento utilizado.

A conversão, ou seja, o rendimento no processo de produção de biomassa (levedura), enfrenta dois aspectos limitantes fundamentais: a eficiência do sistema de aeração quanto a capacidade de dissolver o oxigênio no meio e, a homogeneização do meio, de tal forma que as substâncias nutritivas possam ser assimiladas pelas leveduras.

Em Cuba, os rendimentos alcançados com as tecnologias existentes para a produção de leveduras estão entre 45 e 46\% (ICIDCA, 1986). 
A levedura recuperada apresenta elevado conteúdo de mineral, variando de 9,4 à 14,4\% (Miyada, 1978; Lima, 1983; Moreira, 1984), sendo o potássio seu principal componente (Mattos et al 1984).

Apesar das leveduras apresentarem propriedades químicas que as tornam aceitáveis como ingredientes de ração, podem ocorrer condições fisicas que limitam, ou invalidam seu uso para esse fim, como a não ruptura da parede celular da levedura, que dificulta a utilização das proteínas (Vananuvat, 1977).

Do ponto de vista industrial, a biomassa de levedura é uma matéria-prima importante, contendo diferentes compostos úteis na formação de grande variedade de produtos. A levedura seca e o concentrado protéico são as principais formas de aplicação da biomassa. Também é utilizada para a produção de enzimas, ácidos nucleicos, nucleotídeos e nucleosídeos, lipídios e carboidratos, vitaminas, etc., (Halász \& Láztity, 1991).

A biomassa de levedura pode ser utilizada como célula integral ou, apenas alguns componentes da mesma. A extração das proteinas é realizada após a ruptura celular, e dependendo dos componentes a serem produzidos, diferentes técnicas de separação são utilizadas (Haslasz \& Lásztity, 1991).

Segundo Vananuvat (1977), a parede celular é o principal fator que compromete a utilização dos aminoácidos presentes nas células de leveduras, podendo dificultar a assimilação das proteinas citoplasmáticas do levedo. Se a célula for ingerida intacta, a mesma pode não ser digerida e, com isso, o conteúdo protéico não ser assimilado (Cunningham et al, 1975)

Estudos de Rodrigues et al (1968), mostraram que a alimentação de suínos, em fase de crescimento, a base de ração contendo levedura, não foi prejudicial ao desempenho animal. Para o ser humano, pesquisas de Jacquot (1966) mostram que o valor biológico de levedura é de $87 \%$. 
A composição química e o valor nutritivo das leveduras, bem como dos subprodutos de destilarias, variam conforme o substrato empregado, a levedura utilizada, a concentração de sais, etc, (Sales et al, 1977).

A qualidade da proteina de levedura seca, produzida por $S$. cerevisiae em substrato de melaço de cana-de-açúcar é considerada aceitável quando comparada com a proteína FAO 55 e com o concentrado protéico de soja (Pezzato, 1985).

Pezzato (1985), resume os atributos nutricionais de proteínas de leveduras produzidas por melaço de cana-de-açúcar, em:

- alto teor de proteína com excelente valor biológico e equilibrio calórico/protéico

- fonte de vitaminas do complexo B.

- não higroscópica e sabor suave .

A utilização de levedura como fonte protéica em rações de aves visando produção de carne e ovos, deve ser bem controlada, pois pode ocasionar a "gota visceral" ou "articular", devido ao elevado teor de ácidos nucleicos (DNA e RNA) presentes e, pelo fato das aves não possuírem a enzima uricase (Pezzato, 1985)

Vários estudos foram feitos utilizando essas leveduras recuperadas de fermentação alcoólica para alimentação de suínos e mamiferos (Berto, 1985). Segundo Menten et al, (1984), levedura seca de destilaria de álcool tem sido usada em rações para porcas em gestação.

Dentre as unidades produtoras de etanol, a Usina Santa Luiza, Matão-SP, utiliza as leveduras provenientes da fermentação celular excessiva nas rações para os animais, (Pinotti, 1985).

Korhola e colaboradores (1986) citado por Halasz \& Lasztity (1991), estudaram a incorporação e distribuição de selênio (Se) em leveduras de padaria. Análises de fração de proteína 
mostram que o selênio é solúvel na mesma. A levedura contendo selênio é recomendada para fortificar alimentos pobres, como foi feito na Finlândia. Porém, outros metais podem ser prejudicias às células de leveduras ou aos organismos que as ingerem, ocasionando danos dificeis de prever "a priori" e, quantificar "a posteriori".

O Brasil sendo um grande produtor de açúcar e de álcool, de cana-de-açúcar, possui um alto potencial de produção de levedura que pode ser recuperada em destilarias, ou cultivada em vinhaça ou melaço.

Além do seu conteúdo protéico, a levedura, pode conter elementos tóxicos, prejudiciais aos animais. Essa toxidez pode ser originária do substrato ou toxinas produzidas pelas próprias células (Hanssen, 1981). Esses elementos podem ter origem na aplicação de agrotóxicos, adubos ou inseticidas organo-clorados nas culturas de cana-de-açúcar. Também os metais pesados podem estar presentes, devido à facilidade de serem assimilados pelos microrganismos. Por isso, análises de toxicidade, em microrganismos, deve ser uma prática rotineira (Hanssen, 1982)

A levedura crescendo em meio contendo elevada quantidade de cátions metálicos pode acumular esses metais em suas células. Esse fenômeno pode ser utilizado para preparação de ingredientes de alimentos pobres em microelementos (Koivistonen \& Hattunen, 1986, citado por Halasz \& Lásztity, 1991).

\section{3 - Metal Pesado}

Nos últimos anos, os metais pesados têm recebido muita atenção devido à sua liberação no meio ambiente, causando toxidez a uma extensa variedade de organismos. Os metais pesados compreendem cerca de 40 elementos que apresentam densidade superior ou igual a $5 \mathrm{~g} / \mathrm{cm}^{3}$ (Coker \& Matthews, 1983). Muitos desses metais são essenciais para o crescimento de organismos eucariotos e procariotos e, portanto são exigidos em uma concentração muito pequena. Contudo, alguns dos metais, como cádmio $(\mathrm{Cd})$ e mercúrio $(\mathrm{Hg})$ não são essenciais para o crescimento celular e são extremamente tóxicos em baixas concentrações (Trevors et al, 1986). 
A célula de levedura com a sua complexa parede celular, representa um sítio adicional de adsorção, em relação às células desprovidas de parede. Considera-se a parede celular uma entidade protetora da membrana plasmática e da célula como um todo. Salientando que a membrana da superficie das células é envolvida por uma variedade de interaçôes de considerável interesse interferindo na qualidade do meio ambiente.

Estudo sobre as membranas celulares têm adquirido uma considerável significância por causa das anomalias que aparecem e refletem o "status" de doenças no decorrer do tratamento. A membrana celular e a interação com os fármacos são importantes para o desenvolvimento de novas substâncias e o emprego mais eficiente daquelas que já existem e são utilizados para o tratamento de várias doenças.

Os modelos de arquitetura molecular descrevem as proteinas da superficie celular como uma associação hidrofóbica de lipidios com proteínas em conformação $\alpha$-helicoidal tendo na região periférica os residuos de natureza hidrofóbica formados de glicoproteinas. As estruturas celulares, bem como partículas, quando suspensas em um meio eletrolitico, tal como solução salina fisiológica, adquirem uma carga elétrica que é o resultado da ionização de grupos químicos das macromoléculas da superficie de membrana e ou redistribuição de íons de partículas na interface do meio. Os seguintes quatro tipos de sistemas ionizantes em equilibrio podem ser considerados:

$\begin{array}{lllll}-\mathrm{COO}^{-} & + & \mathrm{H}^{+} & \Rightarrow & -\mathrm{COOH} \\ -\mathrm{NH}_{2} & + & \mathrm{H}^{+} & \Rightarrow & -\mathrm{NH}_{3}{ }^{+} \\ -\mathrm{SO}_{2} \mathrm{O}^{-} & + & \mathrm{H}^{+} & \Rightarrow & -\mathrm{OSO}_{2} \mathrm{OH} \\ \mathrm{OPO}_{3} \mathrm{H}^{-} & + & \mathrm{H}^{\prime} & \Rightarrow & -\mathrm{OPO}_{3} \mathrm{H}_{2}\end{array}$

Seguindo a atração dos íons de um grande volume de meio, os grupos quimicos ionizados organizam-se em uma dupla camada que é formada ao redor da célula. Esta com uma dupla 
camada iônica forma uma unidade cinética, a qual apresenta um potencial que corresponde ao da superficie da célula (Mehrishi \& Wioland, 1983).

Pearson (1969), classificou os ions metálicos de acordo com a "rigidez da escala", definida por sua forte ligação com os íons fluoreto e iodeto. Os íons metálicos formados pela ligação com flúor são chamados duros. Dentre eles estão os íons $\mathrm{Na}, \mathrm{Mg}$ e $\mathrm{Ca}$, os quais estão presentes em grande quantidade nos organismos vivos. Os íons moles estão localizados na outra extremidade da escala Pearson, entre os $\mathrm{Pb}^{2+}, \mathrm{Hg}^{2}$, e $\mathrm{Cd}^{2+}$. Não são conhecidos como nutrientes biológicos e são usualmente tóxicos. Os metais pesados estão entre os íons moles.

Os ions metálicos que estão em estágio intermediário são: $\mathrm{Zn}^{2-}$ e $\mathrm{Co}^{2-}$ e são menos tóxicos, podendo ser detectados nas biomoléculas e participam de reações bioquímicas específicas.

Em sistemas biológicos, os ions duros formam ligações estáveis com os ions $\mathrm{OH}$, $\mathrm{HPO}_{4}{ }^{2-}, \mathrm{CO}_{3}^{2-}, \mathrm{R}-\mathrm{COO}^{-} \mathrm{e}=\mathrm{C}=\mathrm{O}$. Todos esses radicais incluem átomos de oxigênio. Os ions moles se ligam fortemente com $\mathrm{CN}^{-}, \mathrm{R}-\mathrm{S}^{-},-\mathrm{SH}_{-}, \mathrm{NH}_{2}^{-}$e imidazol, isto é, com grupos que contêm átomos de nitrogênio e carbono. A dureza do íon ligante é principalmente, devido a natureza iônica, considerando que na ligação do íon maleável é exibido mais o caráter covalente, (Volesky, 1990)

Embora o cádmio tenha sido descrito como elemento relativamente raro no ambiente (Wood, 1974), posteriormente Babich \& Stotzky (1978) referem-se ao desconhecimento da função biológica do elemento, Iverson \& Brinckman (1978) afirmam que o mesmo encontra-se presente no meio ambiente em baixos niveis. Babich \& Stotzky (1978) relatam que o cádmio está presente como componente de minerais da crosta terrestre, na concentração média de $18 \mathrm{mg} / \mathrm{kg}$.

Os niveis de cádmio no solo usualmente alcançam a faixa de 0,01 à $1,8 \mathrm{mg} / \mathrm{kg}$ (Dundas \& Pawluk, 1977) e a média entre 0,06 e $0,40 \mathrm{mg} / \mathrm{kg}$ (Iverson \& Brinckman, 1978). As concentrações de cádmio na hidrosfera alcançam de 0,07 a $1,02 \mu \mathrm{g} / \mathrm{kg}$ (Benon et $\mathrm{al}, 1978$ citado por 
Trevors, 1986), e a média entre 0,1 a $0,5 \mu \mathrm{g} / \mathrm{kg}$ em água de rio (Henriksen \& Wright, 1978) e 0,1 $\mu \mathrm{g} / \mathrm{kg}$ em água salgada (Iverson \& Brinckman, 1978; Volesky, 1990).

Em meio ambiente aquático ( $\mathrm{pH}$ abaixo de 5,5) os metais podem ser mais solúveis, que em pH intracelular da célula de microrganismo que geralmente encontra-se entre 7,0 e 7,2.

Segundo Mattiazzo-Prezoto (1994), o cádmio ocorre na natureza sempre associado com o zinco, com o qual tem similar estrutura iônica e eletronegatividade, e a grupos contendo enxofre, com o qual tem grande afinidade.

O cádmio pode entrar no meio ambiente, segundo Hutton (1983), citado por Trevors, 1986 e Volesky, 1990, por várias vias antropogênicas, como: sub-produto da fabricação do zinco; combustão do carvão; resíduo de minérios; processos de plaqueamento elétrico; produção de ferro e aço; fertilizantes e pesticidas; estabilizante de cloreto de vinil e cosméticos.

A utilização industrial de cádmio tem provocado um desequilibrio biológico e modificações no transporte desse elemento (Babich \& Stotzky, 1978). As elevadas concentrações de cádmio podem ser encontradas em água de esgoto (Cenci \& Morozzi, 1977), plantas, plâncton marinho e invertebrados (Iverson \& Brinckman, 1978), e ao longo das rodovias pelo atrito dos pneus no asfalto (Omae, 1986)

A toxidade de cádmio é altamente dependente de fatores fisicos, químicos e biológicos (Babich \& Stotzky, 1978, 1980, 1985). O acúmulo de cádmio não tem sido constatado em peixes (Iverson \& Brinckman, 1978).

Quando se considera o uso agronòmico de residuos contendo metais, devem ser feitas previsões do seu comportamento em solos, e neste aspecto, a preocupação mais frequente diz respeito a solubilização, com consequente caminhamento destes metais para o lençol freático e biodisponibilidade para vegetais, com a consequente entrada do metal na cadeia alimentar, (Chaney, 1988). 
Entre as práticas e atividades que podem poluir solos agrícolas com metais pesados citam-se corretivos para acidez, fertilizantes fosfatados, resíduos da indústria siderúrgica, lixo urbano, lodo de esgoto, entre outros (Nogueira, 1990; Amaral, 1993; Egreja - Filho, 1993; Oliveira, 1995; Arteaga, 1996).

A aplicação de lodo de esgoto, em solos agrícolas, está se tornando uma prática comum em virtude do seu teor relativamente elevado de matéria orgânica, que confere a este material um potencial considerável para melhorar a fertilidade do solo. O aumento do custo dos fertilizantes químicos, bem como a demanda de muita energia no processo de incineração de esgoto, torna a sua aplicação em solos agricolas uma alternativa atraente (Jorge, 1991). Ao mesmo tempo, a utilização do lodo de esgoto diminui os problemas ambientais ocasionados pelo acúmulo e pela não utilização destas fontes poluidoras (Arteaga, 1996).

A absorção pelas plantas é uma das principais rotas de entrada dos metais pesados na cadeia alimentar. Em sua maioria, plantas respondem ao aumento na concentração de metais no solo com a absorção. A natureza destas respostas dependerá da sensibilidade individual, da intensidade (concentração e duração), da exposição, do metal propriamente dito e da forma como se encontra, (Tyler, 1990).

Vários são os mecanismos de entrada de metais nas células. Os principais envolvem permeação passiva através da membrana, envolvendo proteinas integrais ou não, no transporte ativo através de moléculas carreadoras e endocitose, (Simikiss \& Taylor, 1989).

Tyler (1990), afirma que a maior parte dos metais pesados são mantidos imobilizados nas cargas negativas da parede celular e muito pouco é levado para o interior da célula. No entanto, Ferguson (1990), afirma que o cádmio presente na planta está normalmente ligado às proteinas citoplasmáticas contendo grupamentos de enxofre, pelo qual o metal se tem grande afinidade.

Segundo Wood \& Wang (1983), numerosos parâmetros químicos são discutidos devido a possibilidade de adsorção de um ín metálico por uma célula viva. Estes incluem a carga do 
metal, o raio iônico, a preferência do metal por ligantes orgânicos, a disponibilidade da concentração do metal, como poluente, ou não, do ambiente $\mathrm{e}$, as reações químicas dos ions metálicos em solução. Em adição, tais critérios como disponibilidade, solubilidade, $\mathrm{pH}$, temperatura, potencial redox, íons competidores, agentes quelantes, ligações não-específicas (para proteinas, argila e matéria orgânica), devem ser considerados.

Kessels et al (1985), atribuíram aos ions $\mathrm{Ca}^{2+}$ a proteção das célulàs de Saccharomyces cerevisiae contra os efeitos tóxicos de cádmio, que apesar de sua presença provocar uma redução no íon cádmio induz a liberação de íons $\mathrm{K}$ da célula.

$\mathrm{O}$ pH do meio ambiente pode interferir na relação metal-microrganismo variando a toxidez. Segundo Babich \& Stotzky (1977), a toxidez com cádmio é maior em pH alcalino $(8,0-9,0)$.

Uma correlação geral entre pH e toxidez pode não ser óbvia, e contradições aparentes podem ser devido às numerosas reações ocorridas (Babich \& Stotzky, 1983). Isso inclue diferença na ação química e toxidez dos íons metálicos e suas formas hidroxiladas, diferindo nos efeitos de pH e na fisiologia. Associa-se a influência do pH do ligante ou com a complexação de metais e demais componentes orgânicos do meio ambiente (Babich \& Stotzky, 1985).

Em células pode ocorrer especial enriquecimento de ions e os coeficientes atingirem a ordem de $10^{5}$ a $10^{7}$. A estabilidade dos coeficientes dos metais diminuem com a baixa basicidade dos ions divalentes, na ordem: $\mathrm{Cu}>\mathrm{Ni}>\mathrm{Co}>\mathrm{Zn}>\mathrm{Fe}>\mathrm{Cd}>\mathrm{Mn}>\mathrm{Mg}>\mathrm{Ca}>\mathrm{Sr}>\mathrm{Ba}>\mathrm{Ra}$. Esta é particularmente quebrada quando se introduz um elemento poluente estranho a essa ordem, porque os ions mais fortemente absorvidos, como cádmio, estão também entre os mais tóxicos para os organismos vivos, (Volesky, 1990).

A toxidade do metal pesado, com respeito a organismos vivos, é afetada por um amplo espectro de fatores bióticos e abióticos (Gadd \& Griffths, 1978; Babich \& Stotzky, 1980). 
O cádmio é conhecido por ser um potente metal tóxico para microrganismos, como bactérias, algas e fungos. Contudo, algumas linhagens microbianas são resistentes a esse metal. $\dot{E}$ sabido que a resistência envolve uma alteração na absorção do metal e não na sua transformação enzimática (Trevors, 1986). A base genética da resistência a metais, mecanismos de absorção e toxidez, são áreas muito atuais de pesquisa em microbiologia.

A remoção por bioabsorbância do cádmio de soluções aquosas tem sido estudada recentemente por muitos pesquisadores (Nakajima, Sakaguchi, Trevors, Gadd, Stratton). Nakajima \& Sakaguchi (1986), chamam a atenção a absorção do cádmio por biomassa de Aspergillus orizae selecionada para uso de fermentações indústriais. A biomassa propagada em "pellets" foi eventualmente imobilizada em suporte de particulas de espuma reticulada. Estudos de isotermas mostraram a possibilidade de absorção de $10 \mathrm{mg}$ de $\mathrm{Cd} / \mathrm{g}$ de biomassa, em pH 8,0, sendo que a absorção diminui em pH baixo.

Tobin et al (1972), investigaram a performance de Rhizopus anhizus como adsorvente para cádmio, verificando que a $\mathrm{pH} 4,0$ foi na proporção $0,25 \mathrm{mmol} / \mathrm{g}$ de biomassa.

Outros microrganismos como Penicillium spimulosum, Mucor racemosus, e Streptomyces sp (11 espécies), exibem a melhor habilidade de absorver o metal (Kurek et al, 1982).

Além disso, várias espécies de leveduras têm a habilidade de sequestrar cádmio do meio, entre elas Saccharomyces uvarum e Candida utilis acumulam aproximadamente $0,13 \mathrm{mmol} \mathrm{Cd} / \mathrm{g}$ de célula. Também Saccharomyces lipolytica e Rhodotorula mucilaginosa, acumulam cádmio em níveis semelhantes aos das bactérias, respectivamente 0,052 e 0,042 mmol Cd/g, (Noris \& Kelly, 1979).

Noris \& Kelly (1979), relatam que os microrganismos acumulam cádmio através de uma via dependente de energia e que células de panificação mortas, adsorvem $0,22 \mathrm{mmols} \mathrm{Cd} / \mathrm{g}$.

A microscopia eletrònica mostrou que o cádmio não está depositado na parede da célula, mas evidenciou sua presença em grânulos eletrodensos no citoplasma de Saccharomyces 
cerevisiae. Entretanto nem todas as células contém depósitos de metais. As células vivas têm aparència normal e não apresentam efeitos tóxicos observáveis do cádmio.

A interação entre microrganismos e metais é considerada sob diferentes aspectos, ocorrendo em três diferentes processos: biolixiviação, tratamento biológico e biossorção ou bioacumulação (Marques \& Garcia, 1992).

A biolixiviação ocorre através de oxidação de sulfeto a sulfato que são solúveis em meio ácido (exceto o $\mathrm{PbSO}_{4}$ que é insolúvel nestas condições). Esta técnica hoje está limitada aos minérios de cobre e urânio, com minérios de baixos teores ou rejeitos minerais. Entretanto a técnica pode abranjer outros minerais sulfetados ( $\mathrm{Zn}, \mathrm{Cd}, \mathrm{Co}, \mathrm{Ni}, \mathrm{Mn})$.

O tratamento biológico consiste na solubilização de impurezas contidas em matérias-primas, e evidenciando o teor do mineral de interesse. Como por exemplo, pode-se destacar a remoção de pirita e enxofre mangânico do carvão, tratamento de minérios de ouro ocluso por sulfetos, tornando-os aptos às aplicações dos métodos convencionais.

O fenômeno de concentração de íons metálicos a partir de soluções contendo microrganismos aquáticos, foi observado à algumas décadas. Entretanto o fato de leveduras mortas exibirem o mesmo fenômeno é uma observação mais recente.

A biosorção consiste na remoção de íons metálicos de soluções para sistemas biológicos (plantas, algas, fungos, leveduras e bactérias). A acumulação pode ocorrer intra ou extracelularmente através de diferentes mecanismos, como ingestão, transporte ativo de ions, troca iônica, complexação, adsorção e preciptação inorgânica.

A acumulação de metais intracelular, na maioria dos processos é realizada por um sistema de transporte de cátions altamente especifico (Marques \& Garcia, 1992). Alguns metais se depositam na superficie dos microrganismos e têm grande potencialidade de aplicação industrial 


\section{3 - MATERIAL E MÉTODOS}

\section{1 - Materiais}

\subsection{1 - Melaço}

O melaço foi doado pela Usina Costa Pinto - Piracicaba-SP safra 91/92, apresentando a seguinte composição:

ART $63,5 \%$

AR $\quad 59,3 \%$

\subsection{2 - Mosto para fermentação, preparado a partir do melaço}

O mosto, não esterilizado, foi preparado por diluição do melaço, apresentando $12 \%$ ART, pH 4,5 e suplementado com $300 \mathrm{mg} / \mathrm{kg}$ nitrogênio $\left(\left(\mathrm{NH}_{4}\right)_{2} \mathrm{SO}_{4}\right), 150 \mathrm{mg} / \mathrm{kg}$ fósforo $\left(\mathrm{K}_{2} \mathrm{HPO}_{4}\right), 50 \mathrm{mg} / \mathrm{kg}$ magnésio $\left(\mathrm{MgCl}_{2} \cdot 6 \mathrm{H}_{2} \mathrm{O}\right)$.

\subsection{3 - Levedura}

Levedura úmida obtida no comércio, marca Fleischmann.

\subsection{4 - Sais de cádmio}

Utilizou-se dois sais de cádmio, um orgânico e outro inorgânico, para contaminar o mosto

$\mathrm{CdC}_{4} \mathrm{H}_{6} \mathrm{O}_{4} 2 \mathrm{H}_{2} \mathrm{O}$ PA (Synth)

$\mathrm{CdCl}_{2} 2 \mathrm{l} / 2 \mathrm{H}_{2} \mathrm{O}$ PA (Quimica Moderna) 


\subsection{5 - Equipamento Experimental}

Foi montado equipamento experimental para condução dos estudos propostos. $\mathrm{O}$ equipamento era constituído de um sistema de chaves (Figura 1), que permitia o controle independente da temperatura, em cada uma das três mini-dornas de polipropileno transparente, com capacidade total de $1000 \mathrm{~mL}$, e volume útil de $500 \mathrm{~mL}$, com tampa de polietileno que suportava uma serpentina para controle da temperatura e um termômetro (Figura 2). A agitação mínima nas três mini-dornas era conseguida por agitadores magnéticos sobre os quais assentavam-se as mesmas. $\mathrm{O}$ esquema de abertura/fechamento das válvulas, para o controle da temperatura é mostrado na Figura 3.

\section{2 - Métodos}

\subsection{1 - Planejamento estatístico do experimento}

O experimento foi realizado segundo o modelo estatístico de " Bloco incompleto no esquema fatorial de $2 \times 4+$ controle" (Cochran \& Cox, 1957). Blocos incompletos porque os tratamentos são em número de nove, e o equipamento utilizado comportava apenas três fermentações por vez. Blocos equilibrados porque cada fermentação (tratamento) foi repetida o mesmo número de vezes, quatro. Preparou-se trinta e seis (36) amostras para atender o experimento. As fermentações foram realizadas segundo o esquema abaixo:

\begin{tabular}{|c|c|c|c|}
\hline \multicolumn{2}{|c|}{ Sal inorgânico $-\mathbf{C d C l}_{2} . \mathbf{2 1} / 2 \mathrm{H}_{\mathbf{2}} \mathbf{O}$} & \multicolumn{2}{|c|}{ Sal orgânico $-\mathrm{CdC}_{\mathbf{4}} \mathbf{H}_{6} \mathbf{O}_{\mathbf{4}} .2 \mathrm{H}_{2} \mathbf{O}$} \\
\hline Dose & Tratamento & Dose & Tratamento \\
\hline 0,5 & 1 & 0,5 & 5 \\
\hline 1,0 & 2 & 1,0 & 6 \\
\hline 2,0 & 3 & 2,0 & 7 \\
\hline 5,0 & 4 & 5,0 & 8 \\
\hline
\end{tabular}

Controle $=$ tratamento 9 
$1^{\text {a }}$ repetição

\begin{tabular}{|l|l|l|}
\hline 1 & 2 & 3 \\
\hline 4 & 5 & 6 \\
\hline 7 & 8 & 9 \\
\hline
\end{tabular}

$3^{\mathrm{a}}$ repetição

\begin{tabular}{|l|l|l|}
\hline 1 & 5 & 9 \\
\hline 7 & 2 & 6 \\
\hline 4 & 8 & 3 \\
\hline
\end{tabular}

$2^{\text {a }}$ repetição

\begin{tabular}{|c|c|c|}
\hline 1 & 4 & 7 \\
\hline 2 & 5 & 8 \\
\hline 3 & 6 & 9 \\
\hline
\end{tabular}

$4^{\text {a }}$ repetição

\begin{tabular}{|l|l|l|}
\hline 1 & 8 & 6 \\
\hline 4 & 2 & 9 \\
\hline 7 & 5 & 3 \\
\hline
\end{tabular}

Os resultados foram analisados pelo programa SANEST (Zonta \& Machado, 1992).

\subsection{2 - Preparo do mosto}

O mosto foi preparado em uma única vez, em volume de 18,0 litros suficiente para realizar toda a pesquisa. Diluiu-se o melaço empregando água destilada, e apresentou as características finais de $12 \%$ ART, dosado pelo método de Somogi \& Nelson, modificado por Amorim (1982) e pH 4,5. Acrescentou-se como nutrientes $300 \mathrm{mg} / \mathrm{kg}$ de nitrogênio, na forma de $\left(\mathrm{NH}_{4}\right)_{2} \mathrm{SO}_{4}$, $150 \mathrm{mg} / \mathrm{kg}$ de fósforo, na forma de $\mathrm{K}_{2} \mathrm{HPO}_{4}$, e $50 \mathrm{mg} / \mathrm{kg}$ de magnésio na forma de $\mathrm{MgCl}_{2} .6 \mathrm{H}_{2} \mathrm{O}$.

Após a homogenização manual, o mesmo foi dividido em frações de $4,0 \mathrm{~kg}$. Cada uma das porções recebeu como contaminantes sais de cádmio, cloreto $\left(\mathrm{CdCl}_{2} 21 / 2 \mathrm{H}_{2} \mathrm{O}\right)$, e acetato $\left(\mathrm{CdC}_{4} \mathrm{H}_{6} . \mathrm{O}_{4} 2 \mathrm{H}_{2} \mathrm{O}\right)$, nas concentrações de 0,$0 ; 0,5 ; 1,0 ; 2,0$ e $5,0 \mathrm{mg} \mathrm{Cd} / \mathrm{kg}$ mosto.

As porções contaminadas foram subdivididas em frações de $0,5 \mathrm{~kg}$, armazenadas em frascos e estocadas a $-20^{\circ} \mathrm{C}$ até o momento de uso, quando eram descongeladas e acrescentava-se $10 \% \mathrm{p} / \mathrm{p}$ de fermento 


\subsection{3 - Preparo do inóculo}

O fermento foi adquirido no comércio, de uma única partida, na forma de pacotes de $500 \mathrm{~g}$, os quais foram homogenizados, através de quebra dos blocos, e estocados em geladeira até o momento do uso, quando era controlada a viabilidade empregando o corante eritrosina (Sharf, 1972).

Todas as fermentações duraram 4 horas cada, e foram mantidas a $30^{\circ} \mathrm{C}$, tendo sido consideradas finalizadas por medidas de ${ }^{\circ}$ Bríx coincidentes, de trinta em trinta minutos, e pelo término da formação de espuma.

\subsection{4 - Determinação da viabilidade celular}

Ao final das fermentações retirou-se aliquotas de $5,0 \mathrm{ml}$ para contagem de viabilidade celular (método Sharf, 1972).

\subsection{5 - Determinação do peso úmido}

Após terminada cada fermentação o vinho foi centrifugado a $12 \times 10^{3} \mathrm{G}$, em ultra centrífuga CEPA, Tipo LE, com rotor vertical de separação contínua sólido-líquido O peso úmido total da levedura recuperada foi medido para cada ensaio (balança analítica $0,001 \mathrm{~g}$ ), para os diferentes sais.

\subsection{6 - Determinação da massa específica}

Do líquido metabólico quantificou-se o etanol, após destilação em densímetro digital : Calculating Digital, Density Meter AP Paar DMA 45, determinando-se a massa especifica a $20^{\circ} \mathrm{C}$, sendo que o teor alcoólico era transformado em ${ }^{\circ} \mathrm{GL}$

\subsection{7 - Dosagem de cádmio}

Após a secagem da levedura, 1,25g foram submetidas a digestão sulfo-nitroperclórica $\left(\mathrm{H}_{2} \mathrm{SO}_{4}: \mathrm{HNO}_{3}: \mathrm{HClO}_{4}\right.$, na proporção de 2:5:3). Colocou-se as amostras de biomassa em tubos de ensaio de $20 \times 250 \mathrm{~mm}$ e aqueceu-se a $150^{\circ} \mathrm{C}$, por cinco horas, até a total descoloração, quando o material era considerado mineralizado 
As amostras de biomassa mineralizadas foram diluídas até $25 \mathrm{ml}$ e submetidas a análise. O método prevê uma sensibilidade de até $0,011 \mu \mathrm{g} / \mathrm{mL}$ tantas $\mathrm{mg} / \mathrm{kg}$. Os teores de cádmio foram transformados em $\mathrm{mg} / \mathrm{kg}$ de levedura.

O cádmio foi quantificado em espectrofotômetro de absorção atômica, Marca VARIAN - AA 175 séries.

\subsection{8 - Dosagem de nitrogênio total}

Da biomassa seca, analisou-se o nitrogênio total segundo o método microKjeldahl, que prevê digestão sulfúrica com catalizadores, seguida de destilação e titulação, (Silva, 1990). 


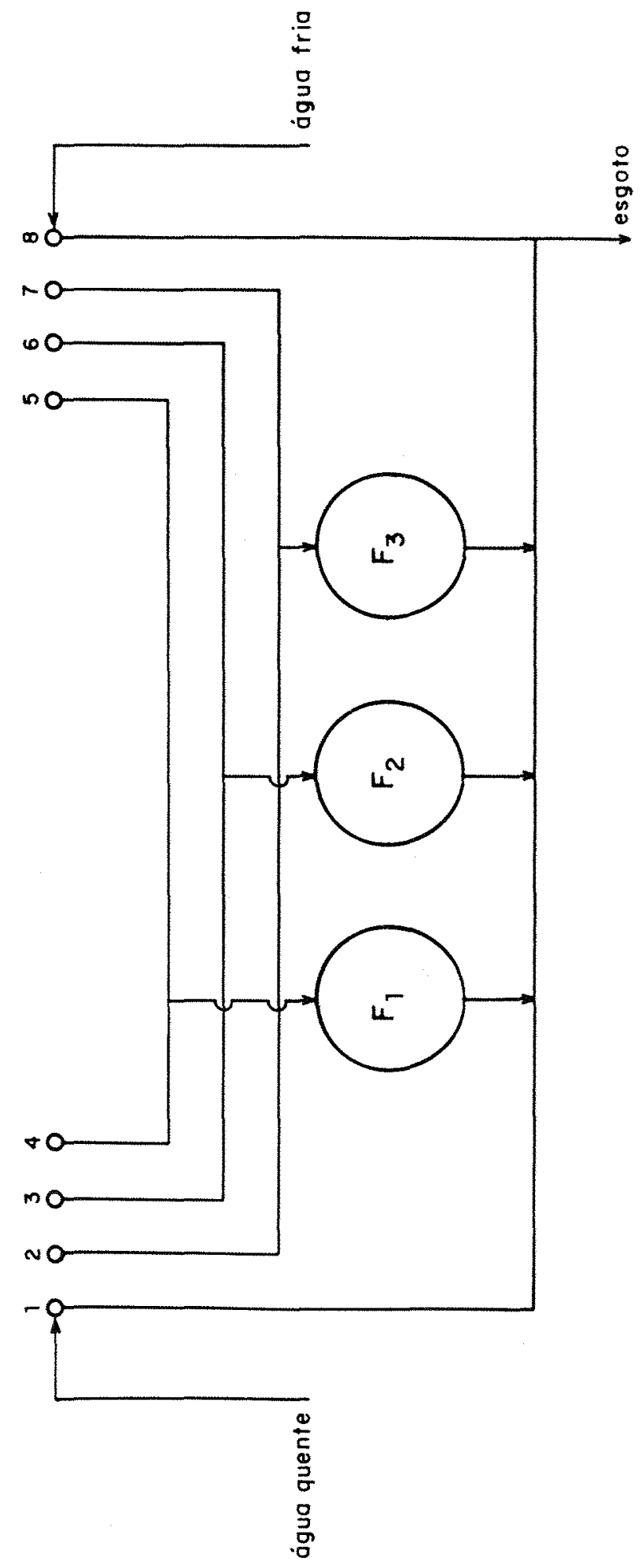

Figura 1 - Diagrama do Sistema para fermentação simultânea, empregando três dornas com controle de temperatura. 


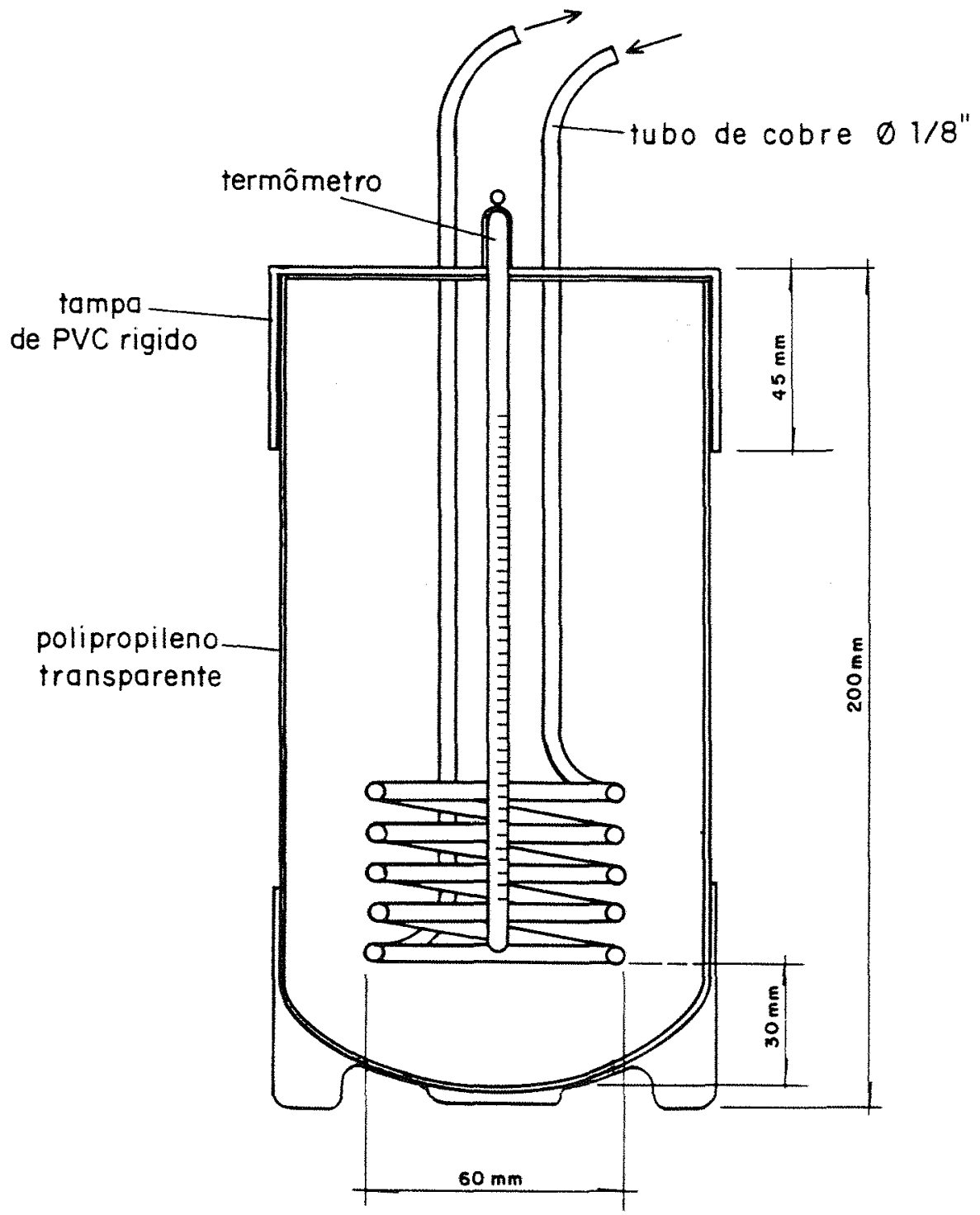

Figura 2 - Diagrama do sistema experimental de fermentação denominado de mini-dorna, confeccionada em polipropileno, contendo uma serpentina com água circulando na temperatura programada 


\begin{tabular}{|c|c|c|c|c|c|c|c|c|c|}
\hline \multicolumn{10}{|c|}{ Válvulas } \\
\hline \multicolumn{4}{|c|}{ Quentes } & \multicolumn{4}{|c|}{ Frias } & \multicolumn{2}{|c|}{ Fermentador } \\
\hline 1 & 2 & 3 & 4 & 5 & 6 & 7 & 8 & Aquece & Esfria \\
\hline$X$ & $X$ & $\mathrm{O}$ & $X$ & $X$ & $X$ & $\mathrm{O}$ & $X$ & $\mathrm{~F} 2$ & $\mathrm{~F} 1$ \\
\hline$X$ & $X$ & $X$ & $\mathrm{O}$ & $X$ & $\mathrm{O}$ & $X$ & $X$ & $\mathrm{~F} 2$ & $\mathrm{~F} 1$ \\
\hline $\mathrm{X}$ & $\mathrm{O}$ & $X$ & $X$ & $\mathrm{O}$ & $X$ & $\mathrm{X}$ & $X$ & $\mathrm{Fl}$ & F3 \\
\hline $\mathrm{X}$ & $X$ & $\mathrm{X}$ & $\mathrm{O}$ & $X$ & $X$ & $\mathrm{O}$ & $X$ & F3 & $\mathrm{F} 1$ \\
\hline $\mathrm{X}$ & $X$ & $\mathrm{O}$ & $X$ & $\mathrm{O}$ & $\mathrm{X}$ & $X$ & $X$ & $\mathrm{~F} 2$ & F3 \\
\hline$X$ & $\mathrm{O}$ & $X$ & $X$ & $X$ & $\mathrm{O}$ & $X$ & $X$ & F1 & $\mathrm{F} 2$ \\
\hline $\mathrm{O}$ & $X$ & $X$ & $X$ & $X$ & $X$ & $\mathrm{O}$ & $X$ & $-\ldots$ & $\mathrm{F} 1$ \\
\hline $\mathrm{O}$ & $X$ & $X$ & $X$ & $X$ & $\mathrm{O}$ & $X$ & $X$ & -- & $\mathrm{F} 2$ \\
\hline $\mathrm{O}$ & $\mathrm{X}$ & $X$ & $\mathrm{X}$ & $\mathrm{O}$ & $\mathrm{X}$ & $X$ & $\mathrm{X}$ & -- & F3 \\
\hline$X$ & $\mathrm{O}$ & $X$ & $X$ & $X$ & $X$ & $X$ & $\mathrm{O}$ & $\mathrm{F} 1$ & -- \\
\hline$X$ & $X$ & $\mathrm{O}$ & $X$ & $\mathrm{X}$ & $\mathrm{X}$ & $X$ & $\mathrm{O}$ & $\mathrm{F} 2$ & --- \\
\hline $\mathrm{O}$ & $X$ & $X$ & $X$ & $\mathrm{O}$ & $\mathrm{O}$ & $\mathrm{O}$ & $X$ & -- & $\mathrm{F} 1 \mathrm{~F} 2 \mathrm{~F} 3$ \\
\hline $\mathrm{O}$ & $X$ & $X$ & $X$ & $X$ & $\mathrm{O}$ & $\mathrm{O}$ & $X$ & -- & $F 1 F 2$ \\
\hline $\mathrm{O}$ & $X$ & $X$ & $X$ & $\mathrm{O}$ & $X$ & $\mathrm{O}$ & $X$ & --- & F1 F3 \\
\hline $\mathrm{O}$ & $X$ & $X$ & $X$ & $\mathrm{O}$ & $\mathrm{O}$ & $X$ & $X$ & -- & F2 F3 \\
\hline$X$ & $\mathrm{O}$ & $\mathrm{O}$ & $\mathrm{O}$ & $X$ & $X$ & $\mathrm{X}$ & $\mathrm{O}$ & F1 F2 F3 & $-\cdots$ \\
\hline$X$ & $\mathrm{O}$ & $\mathrm{O}$ & $X$ & $X$ & $X$ & $X$ & $\mathrm{O}$ & F2 F3 & -- \\
\hline$X$ & $\mathrm{O}$ & $\mathrm{X}$ & $\mathrm{O}$ & $X$ & $X$ & $X$ & $\mathrm{O}$ & F1 F3 & -- \\
\hline$X$ & $X$ & $\mathrm{O}$ & $\mathrm{O}$ & $\mathrm{X}$ & $X$ & $X$ & $\mathrm{O}$ & $\mathrm{F} 2 \mathrm{~F} 3$ & -- \\
\hline$X$ & $X$ & $X$ & $\mathrm{O}$ & $X$ & $\mathrm{O}$ & $\mathrm{O}$ & $X$ & F3 & F1 F2 \\
\hline$X$ & $X$ & $\mathrm{O}$ & $X$ & $\mathrm{O}$ & $X$ & $\mathrm{O}$ & $X$ & $\mathrm{~F} 2$ & F1 F3 \\
\hline$X$ & $\mathrm{O}$ & $X$ & $X$ & $\mathrm{O}$ & $\mathrm{O}$ & $X$ & $X$ & $\mathrm{Fl}$ & F2 F3 \\
\hline$X$ & $X$ & $\mathrm{O}$ & $\mathrm{O}$ & $X$ & $X$ & $\mathrm{O}$ & $X$ & F2 F3 & $\mathrm{F} 1$ \\
\hline $\mathrm{X}$ & $\mathrm{O}$ & $\mathrm{O}$ & $X$ & $\mathrm{O}$ & $X$ & $X$ & $X$ & $\mathrm{~F} 2 \mathrm{~F} 1$ & F3 \\
\hline$X$ & $\mathrm{O}$ & $X$ & $\mathrm{O}$ & $X$ & $\mathrm{O}$ & $X$ & $X$ & F1 F3 & $\mathrm{F} 2$ \\
\hline
\end{tabular}

Legenda:

$\mathrm{X}=$ fechada $\mathrm{O}=$ aberta

Figura 3 - Esquema de fechamento/abertura de válvulas para controle de entrada e saida de água controle da temperatura nas mini-dornas. 


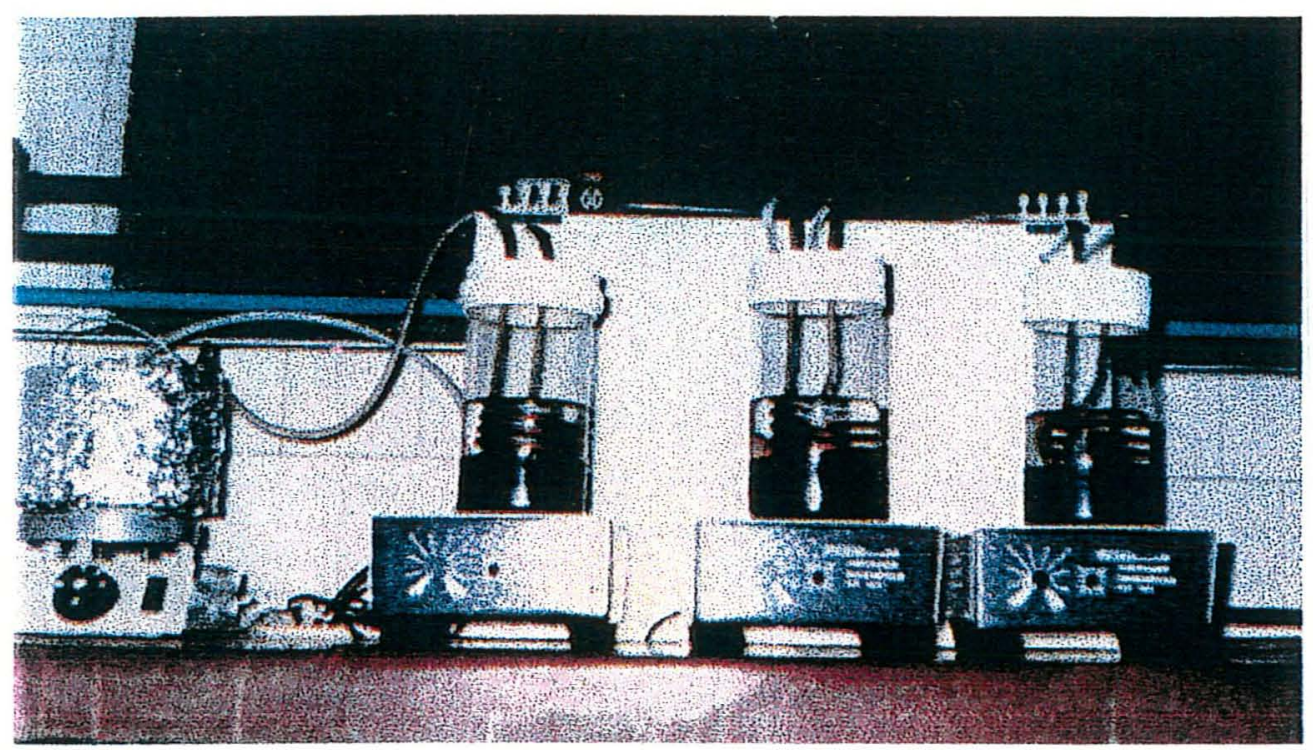

Foto 1- Dorna de fermentação. 


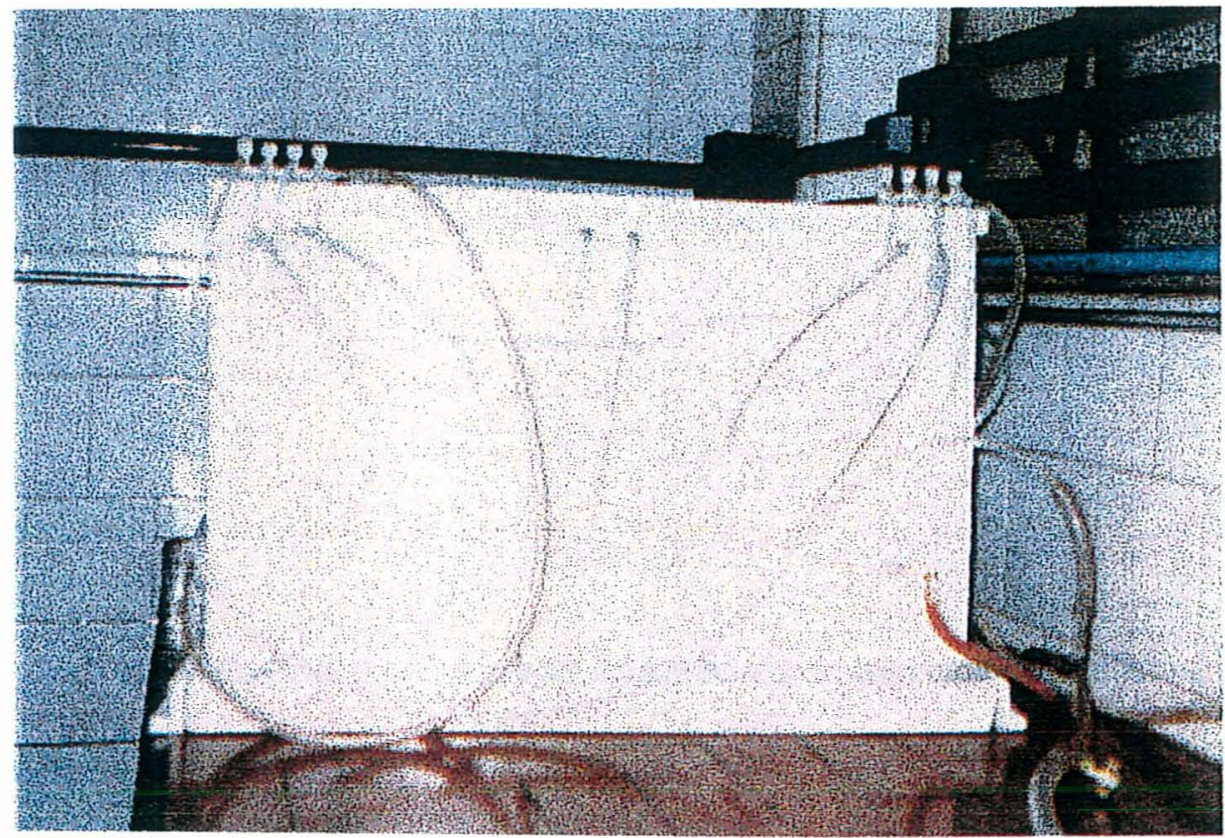

Foto 2 - Sistema de tubulação para controle de temperatura. 


\section{4. - RESULTADOS E DISCUSSÕES}

\section{1 - Equipamento utilizado no experimento}

O fermentador com mini-dornas em triplicata, bem como a montagem das tubulações do sistema de controle de temperatura podem ser vistos nas Fotos 1 e 2 . O equipamento construido não apresentou nenhum problema durante o experimento, com a vantagem de poder controlar independentemente a temperatura nas mini-dornas.

\section{2 -Teor de cádmio na levedura}

Em todos os niveis de contaminações propostos e estudados, houve acumulação, como mostram a Tabela 6 e Figura 4.

Tabela 6 - Concentração de cadmio $(\mathrm{mg} / \mathrm{kg})$ na levedura

\begin{tabular}{ccccc|ccccc}
\hline MATERIAIS & \multicolumn{8}{c}{ SAIS (mg/kg) } \\
\cline { 2 - 9 } Mosto & 0,5 & 1,0 & 2,0 & 5,0 & 0,5 & 1,0 & 2,0 & 5,0 \\
\hline Levedura & 0,210 & 0,700 & 1,250 & 1,890 & 0,540 & 0,840 & 1,310 & 1,970 \\
\%Absorção & 42,0 & 70,0 & 62,5 & 37,8 & 108,0 & 84,0 & 65,5 & 39,4 \\
\hline
\end{tabular}




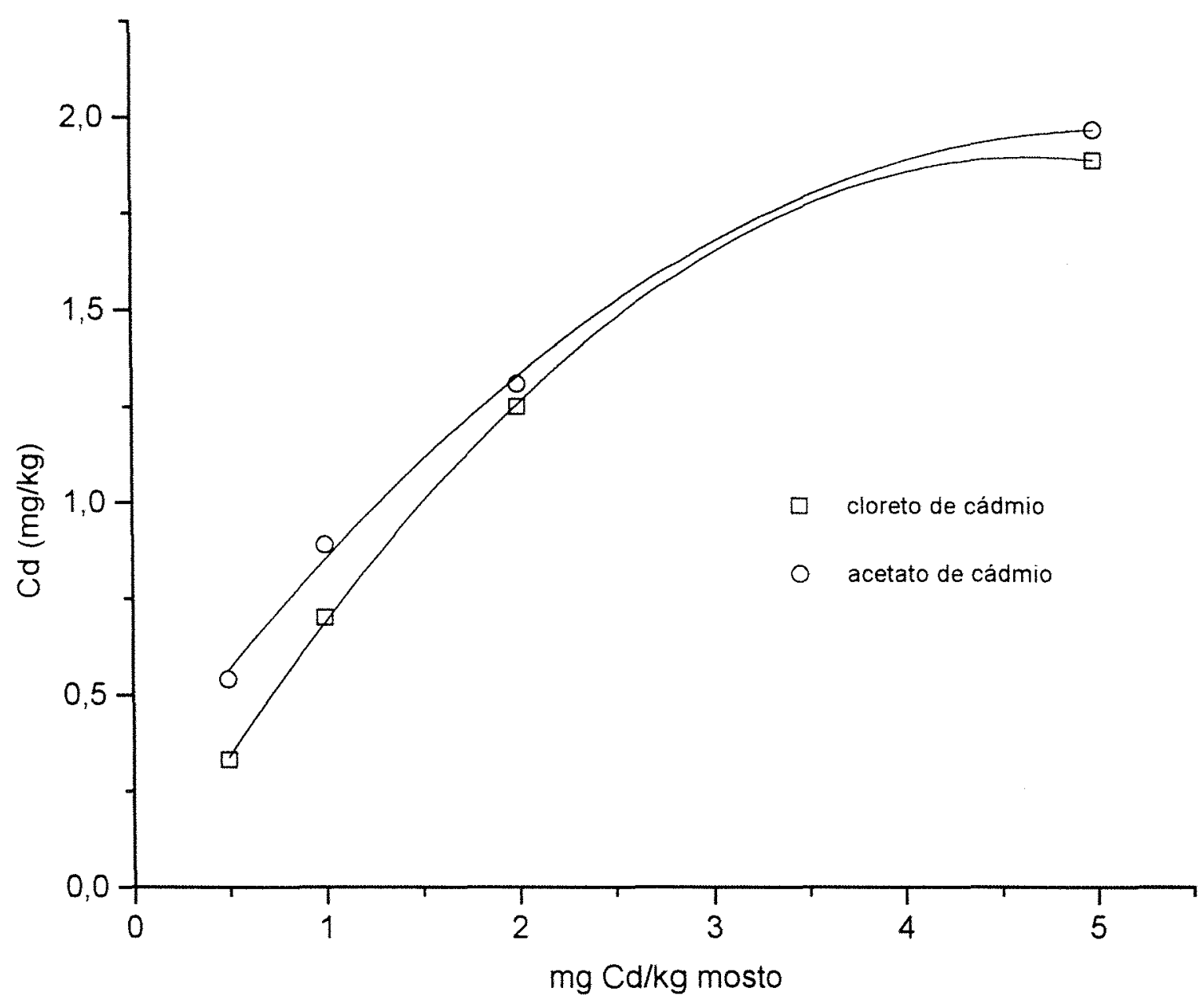

Figura 4 - Concentração de cloreto de cádmio e acetato de cádmio, absorvido pela levedura durante o processo de fermentação, por $4 \mathrm{~h}$ a $30^{\circ} \mathrm{C}$ em mosto de melaço $12 \%$ ART enriquecido e quantificado por absorção atômica. 
Os teores que aparecem na levedura bruta mostram uma correlação com os teores nos mostos. Embora a levedura bruta centrifugada estivesse úmida de vinho, os teores de umidade não são suficientes para justificar a eventual presença de cádmio apenas no vinho residual. Portanto, os teores encontrados na levedura bruta são devidos à biosorção e/ou bioacumulação, não sendo possível, nas condições estudadas, diferenciar quantitativamente a ação de cada um desses mecanismos.

Contudo, sob quaisquer aspectos, a acumulação global ou, total, fica estabelecida, no estudo levado a efeito.

A acumulação de até $2,0 \mathrm{mg} / \mathrm{kg}$ de cádmio na levedura bruta, não diretamente proporcional aos teores de contaminações nos mostos deve ser atribuida às muito pouco conhecidas interações entre o elemento na forma de cátion ou metálica, e os compostos orgânicos e inorgânicos presentes em um meio complexo como o melaço.

A ação individual de grupos quelantes, de sequestradores, de ligações como RS , $\mathrm{S}, \mathrm{SO}_{4}{ }^{2-}, \mathrm{F}, \mathrm{NO}_{3}^{-}, \mathrm{NH}_{3}$, etc, em um meio complexo como o melaço é desconhecida, bem conı as interações no ambiente fermentativo do mosto de melaço, (Remacle, 1990).

A análise estatística mostra que os valores obtidos, do cádmio, por espectroscopia de absorção atômica, foram significativos ao nivel de $99 \%$ de confiança (Apêndice ), e o gráfico evidencia o acúmulo crescente dos metais, em todos os niveis de contaminações, como está registrado na Tabela 6 e Figura 4.

Além disso, as porcentagens de absorção ficaram entre 37,8 e $84 \%$ indicando ser a levedura um microrganismo capaz de absorver metais mesmo quando o meio de cultura é altamentecomplexo, como o melaço. Substratos complexos de composição química pouco definida podem comprometer os sitios de absorção ou adsorção na parede celular. 
Quando o comportamento dos sítios de ligação da superficie celular fica alterado, a levedura perde o seu potencial biológico em diferentes graus, chegando a perder a viabilidade.

O cádmio, sendo um dos compostos pertencentes ao grupo de metais pesados, nas condições de fermentação, e pelos parâmetros analisados mostra acúmulo nas células, estatisticamente significante, relacionado com as concentrações no mosto, (Tabela 6 e Figura 4).

Pelos dados de literatura não se constatou uma variação proporcional para metais adsorvidos em biomassa, como ocorre com os azos compostos (Barbosa, 1995).

O trabalho avaliou a possibilidade de acumulação do ín cádmio nos diferentes sais, considerando que para a levedura o cloro é um elemento que auxilia na permeação de membrana, e que o radical acetato pode não ser tão benéfico para a célula.

\section{3 - Teor alcoólico no vinho}

As Tabelas 7 e 8 apresentam os teores alcoólicos nos vinhos das fermentações, com diferentes níveis de contaminações de cádmio. Do ponto de vista estatístico pode-se afirmar que houve uma diferença significativa entre os mostos contaminados e a testemunha, tanto utilizando-se cloreto ou acetato de cádmio, nas condições experimentais utillizadas. A Figura 5, mostra os teores alcoólicos dos vinhos da fermentação, contaminados com os dois sais de cádmio.

Tabela 7 - Massa especifica nos vinhos contaminados com cloreto de cádmio

\begin{tabular}{cccccc}
\hline Materiais & Controle & \multicolumn{3}{c}{$\mathbf{C d C l}_{\mathbf{2}} \mathbf{2} \mathbf{1} \mathbf{2} \mathbf{H}_{\mathbf{2}} \mathbf{O} \mathbf{( \mathbf { m g } / \mathbf { k g } )}$} \\
\hline Mosto & 0,0 & 0,5 & 1,0 & 2,0 & 5,0 \\
Massa especifica do destilado & 0,9913 & 0,9917 & 0,9917 & 0,9919 & 0,9920 \\
\hline
\end{tabular}


Tabela 8 - Massa específica nos vinhos contaminados com acetato de cádmio

\begin{tabular}{cccccc}
\hline Materiais & Controle & \multicolumn{4}{c}{$\mathrm{CdC}_{4} \mathbf{H}_{\mathbf{6}} \mathbf{O}_{\mathbf{4}} \mathbf{2} \mathbf{H}_{\mathbf{2}} \mathbf{O}$ (mg/kg) } \\
\hline Mosto & 0,0 & 0,5 & 1,0 & 2,0 & 5,0 \\
Massa específica do destilado & 0,9913 & 0,9917 & 0,9918 & 0,9917 & 0,9916 \\
\hline
\end{tabular}

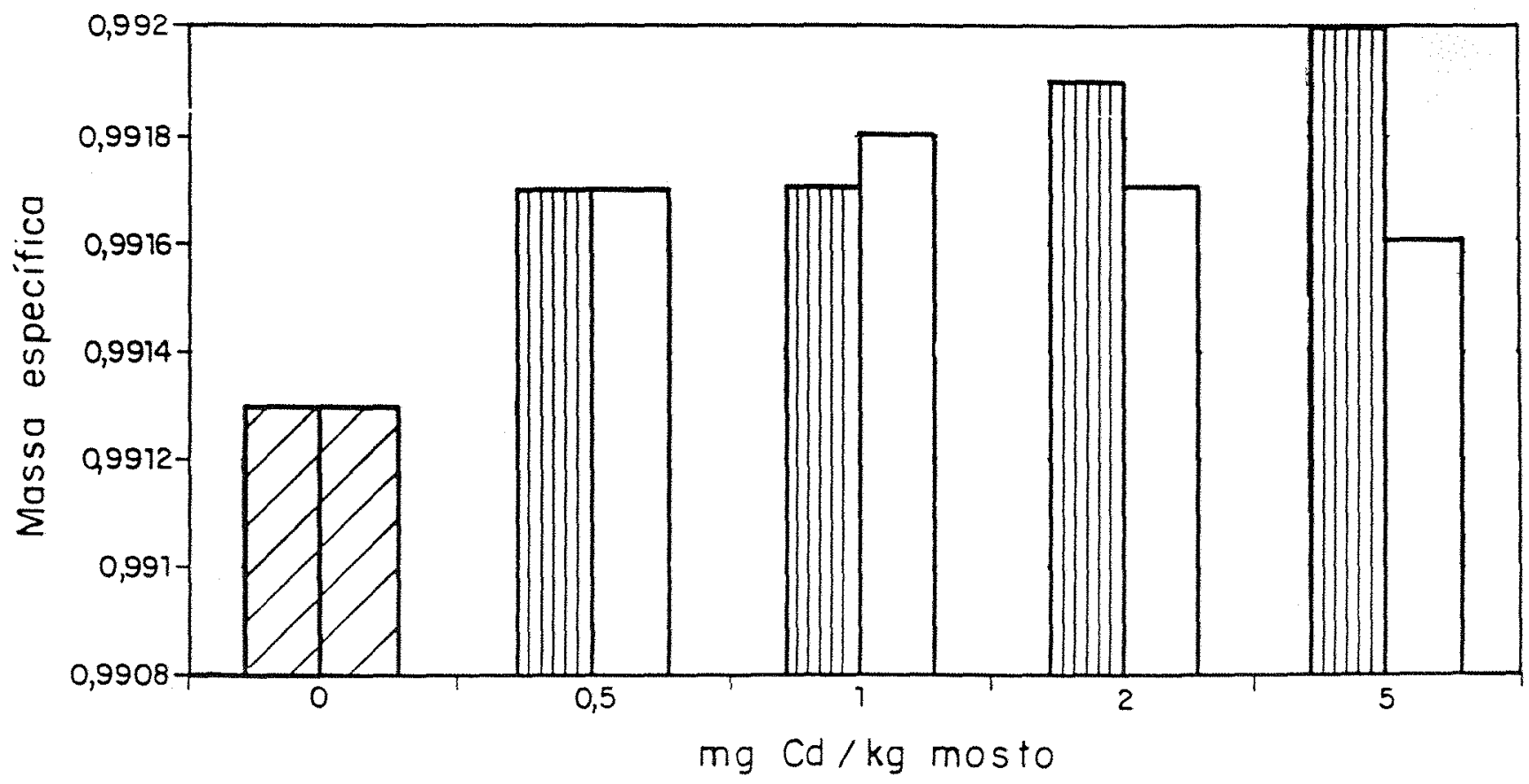

Figura 5 - Massas especificas obtidas no vinho da fermentação, $\mathbb{Z}$ controle, e contaminadas com $\mathrm{CdCl}_{2} 2.1 / 2 \mathrm{H}_{2} \mathrm{O}$ II e $\mathrm{CdC}_{4} \mathrm{H}_{6} \mathrm{O}_{4} \cdot 2 \mathrm{H}_{2} \mathrm{O}$, em mosto contendo $12 \%$ ART, durante $4 \mathrm{~h}$ a $30^{\circ} \mathrm{C}$, quantificados por densitometria. 
A fermentação, usando melaço, para obtenção de álcool é bastante tradicional e aplicada no Brasil. Os mostos derivados destes substratos apresentam as mais variadas cargas, quer benéficas, quer tóxicas. Estas podem ser resultado do acúmulo de resíduos de agrotóxicos, produtos adsorvidos pelas plantas na lavoura, substâncias provenientes dos diferentes tipos de solo de cerrado, que são bastante variados. Além disso, os produtos podem ser resultantes do metabolismo microbiano e da introdução de produtos químicos, como o ácido sulfúrico, na etapa de acidificação do mosto. Nesta condição pode ocorrer abaixamentos drásticos do $\mathrm{pH}$ do mosto pode induzir corrosão dos equipamentos e consequente solubilização de metais, que posteriormente poderão ser adsorvidos pelas células e comprometer a fermentação.

Mesmo diante de condições eventualmente tão adversas, Saccharomyces cerevisice mostrou grande potencial de fermentação e mesmo quando contaminada artificialmente com sais de cloreto e acetato de cádmio, na proporção de $5,0 \mathrm{mg} / \mathrm{kg}$ de mosto, a levedura não foi afetada no seu desempenho fermentativo (Tabela 7 e Figura 5).

\section{4 - Viabilidade celular}

A viabilidade celular da levedura, após as fermentações, são mostradas nas Tabelas 9 e 10 e nas Figuras 6, 7,8 e 9. Demonstram-se também aqui, que não existem alterações nos diferentes niveis de contaminações. Recordamos que os experimentos foram realizados nas mesmas condições isotérmicas a $30^{\circ} \mathrm{C}$, e não houve reaproveitamento das células. 
Tabela 9 - Porcentagem da viabilidade celular da levedura recuperada através de centrifugação do mosto contaminado com cloreto de cádmio, após fermentação.

\begin{tabular}{ccccccc}
\hline Viabilidade celular & Controle & \multicolumn{3}{c}{ Concentração no mosto mg/kg } \\
\hline mg/kg no mosto & 0,0 & 0,5 & 1,0 & 2,0 & 5,0 \\
Células vivas & 98,95 & 98,95 & 98,95 & 98,95 & 98,95 \\
Células mortas & 1,05 & 1,05 & 1,05 & 1,05 & 1,05 \\
Brotamento & 49,50 & 49,0 & 48,75 & 48,75 & 48,75 \\
Viabilidade brotos & 94,28 & 94,23 & 94,20 & 94,19 & 94,20 \\
\hline
\end{tabular}

Tabela 10 - Porcentagem da viabilidade celular da levedura recuperada através da centrifugação do mosto contaminado com acetato de cádmio, após fermentação.

\begin{tabular}{cccccc}
\hline Viabilidade celular & Controle & \multicolumn{4}{c}{ Concentração no mosto mg/kg } \\
\hline mg/kg no mosto & 0,0 & 0,5 & 1,0 & 2,0 & 5,0 \\
Células vivas & 98,95 & 98,95 & 98,95 & 98,95 & 98,95 \\
Células mortas & 1,05 & 1,05 & 1,05 & 1,06 & 1,05 \\
Brotamento & 49,50 & 49,25 & 48,75 & 48,23 & 48,75 \\
Viabilidade brotos & 94,28 & 94,25 & 94,20 & 94,14 & 94,20 \\
\hline
\end{tabular}

Outro aspecto considerado foi a condição biológica do fermento, como mostram

as Tabelas 9 e 10 .

Embora a estatística não mostre significância, para viabilidade celular (células vivas e mortas), a viabilidade de brotos e porcentagem de brotamento, mostram tendência, em relação ao controle, de queda da viabilidade e da porcentagem de brotamento e da sua viabilidade, que provavelmente reciclagens consecutivas poderiam, ao longo do tempo, revelar não uma toxicidade aguda, porém, crônica de efeitos bastante acentuados no rendimento fermentativo. 


\section{5 - Peso úmido da levedura}

Embora o peso úmido tenha, pelo próprio método, um erro intrínseco, pode-se verificar que ocorre variação quando o cádmio está presente, mesmo não sendo comprovado estatisticamente.

Embora os resultados mostrados na Tabela 11, numa primeira análise, sugere que existem diferenças nos valores medidos, estatisticamente também ficou demonstrado que esses parâmetros para os sais, não mantém diferenças significativas, sendo necessário entretanto lembrar que aos valores devem ser acrescentados os erros sistemáticos, atribuídos ao equipamento.

Tabela 11 - Peso úmido, em gramas, da levedura recuperada, após fermentação de mostos contaminados com sais de cádmio.

\begin{tabular}{|c|c|c|c|c|c|}
\hline \multirow[t]{2}{*}{ Sais } & \multicolumn{4}{|c|}{ Mosto $\mathrm{mg} / \mathrm{kg}$} & \multirow[t]{2}{*}{ Controle } \\
\hline & 0,5 & 1,0 & 2,0 & 5,0 & \\
\hline $\mathrm{CdCl}_{2} 21 / 2 \mathrm{H}_{2} \mathrm{O}$ & 58,55 & 60,43 & 57,43 & 56,11 & 58,37 \\
\hline $\mathrm{CdC}_{4} \mathrm{H}_{6} \mathrm{O}_{4} 2 \mathrm{H}_{2} \mathrm{O}$ & 56,27 & 56,75 & 58,69 & 58,22 & 58,37 \\
\hline
\end{tabular}

\section{6 - Porcentagem de proteína bruta $(f=6,25)$ na levedura}

Os teores de proteina bruta na levedura, encontram-se na Tabela 12. Da mesma forma que nos itens anteriores desse capítulo, nenhum dos resultados podem ser considerados numericamente relevantes, quando comparam-se os dados de cada sal, utilizando-se também os mesmos critérios, (tratamento estatístico). 
Tabela 12 - Proteína bruta, em gramas, da levedura, recuperada após fermentação de mostos contaminados com sais de cádmio.

\begin{tabular}{|c|c|c|c|c|c|}
\hline \multirow[t]{2}{*}{ Sais } & \multicolumn{4}{|c|}{ Mosto $\mathrm{mg} / \mathrm{kg}$} & \multirow[t]{2}{*}{ Controle } \\
\hline & 0,5 & 1,0 & 2,0 & 5,0 & \\
\hline $\mathrm{CdCl}_{2} 21 / 2 \mathrm{H}_{2} \mathrm{O}$ & 37,06 & 37,20 & 37,10 & 36,32 & 35,30 \\
\hline $\mathrm{CdC}_{4} \mathrm{H}_{6} \mathrm{O}_{4} 2 \mathrm{H}_{2} \mathrm{O}$ & 38,82 & 34,27 & 35,75 & 35,16 & 35,30 \\
\hline
\end{tabular}

A Tabela 12 revela informações que devem ser consideradas quando se afirmam sobre a toxicidade do cádmio.

De alguma forma, em relação ao controle, as cẻlulas afetadas pelo cádmio (cloreto e acetato), tiveram melhores índices de proteina bruta. Isto pode ser reflexo de bloqueios de vias metabólicas que favoreça a permanência de produtos nitrogenados dentro da célula fazendo com que as mesmas fujam de sua normalidade metabólica, numa determinada condição e passem a acumular compostos nitrogenados. Nas condições estudadas, não se pode afirmar que estes compostos sejam realmente traduziveis em proteina, porém, houve um aumento do teor de nitrogênio na célula, não estatisticamente significativo. 


\section{5 - CONCLUSÕES}

- Ficou evidenciada a acumulação de cádmio por Saccharomyces cerevisiae fermentando mosto de melaço, e, que essa acumulação não é diretamente proporcional à concentração do metal no mosto, embora, haja correlação entre o teor do metal na levedura e o teor do mesmo no mosto.

- Foram observadas diferenças de comportmento da levedura em função da concentração e do sal utilizado, sendo maior a acumulação quando o sal utilizado foi acetato de cádmio do que com cloreto de c'sdmio, isto nas quatro doses sub-tóxicas estudadas.

- Nas condições estudadas, a viabilidade da levedura não foi afetada, podendo ser aproveitada em outros processos fermentativos.

- Não foram detectadas diferenças significativas no peso úmido da levedura, após fermentação.

- Não foi afetado, significativamente, o rendimento fermentativo.

- O rendimento alcoólico, nas condições experimentais foi afetado significativamente nas amostras contaminadas, quando comparadas com a testemunha sem contaminação.

- Foi constatado um aumento do teor de nitrogênio total, traduzido em proteina bruta, quando a levedura foi exposta a dose sub-tóxica de $0,5 \mathrm{mg} \mathrm{Cd} / \mathrm{kg}$ mosto. Contudo, um aumento no nitrogênio total corresponde, realmente, a um aumento nos compostos proteicos nas células. 


\section{6 - REFERÊNCIAS BIBLIOGRÁFICAS}

AMARAL, A. S. Liberação de zinco, ferro, manganês, cádmio e chumbo de quatro corretivos de acidez do solo e absorção por plantas de alface em dois solos com diferentes texturas. Viçosa, 1993. 87p. Tese (Mestrado). Universidade Federal de Viçosa.

AMORIM, H. V. Progressos na técnica de fermentação alcoólica no Brasil Álcool e Açúcar, v. 2, n. 4 , p. $50-56,1982$.

ÂNGELIS, D. F. de ; THOMAZINI, E. E. M. Leveduras. Uma fonte suplementar de alimentos. Revista Brasileira de Qúmica (Ciência \& Indústria). v. 88, n. 533, p. 113-115, 1980.

ARTEAGA, D. H. Dinâmica de cádmio, chumbo, cobre, níquel e zinco no sistema solo-planta. Viçosa, 1996. 90p. Tese (Mestrado) Universidade Federal de Viçosa.

BABICH, H.; STOTZKY, G. Effects and cadmium on the biota: influence on environmental factors. Advances in Applied Microbiology, v. 23, p. 55-117, 1978.

BABICH, H.; STOTZKY, G. Environmental factors that influence the toxicity of heavy metals and gaseous pollutants to microorganisms. Critical Review Microbiology, v. 8, p. 99-145, 1980

BABICH, H.; STOTZKY, G. Heavy metal toxicity to microbe-mediated ecologic processes: a review and potential application to regulatory policies. Environmental Research, v. 36, p. 111-137, 1985. 
BABICH, H. ; STOTZKY, G. Influence of chemical speciation on the toxicity of heavy metals to the microbiota. In: NRIAGU, J. O. ed. Aquatic toxicology, New York: Wiley \& Sons. p. 1-46, 1983.

BABICH, H; STOTZKY, G. Sensitivity of various bacteria, including actinomycetes, and fungi to cadmium and the influence of $\mathrm{pH}$ on sensitivity. Applied Environmental Microbiology, v. 33, p. $681-695,1977$.

BARBOSA, J. R. Estudos da interação adsortiva entre os corantes "direct red"23 e "reative procion red"HE3B e células de Saccharomves cerevisiae. Rio Claro, 1995.93p. Tese (Mestrado) Instituto de Biociências, Universidade Estadual Paulista.

BARNETT, J. A. The taxonomy of the genus Saccharomyces Meyen ex Reess: a short review for nontaxonomists. Yeast, v. 8, p. 1-23, 1992.

BARNETT, J. A.; PAYNE, R. W.; YARROW, D. Yeast: characteristics and identification. 3 ed. Cambridge: Cambridge University Press, 1986. $81 \mathrm{lp}$.

BERTO, D. A. Levedura seca de destilaria de álcool de cana-de-açúcar (Saccharomyces ssp) na alimentação de leitões em recria. Piracicaba, 1985. 133p. Tese (Mestrado) Escola Superior de Agricultura "Luiz de Queiroz", Universidade de São Paulo.

BOUCOURT, R. Protein supplementation with yeast in live or dead forms in final molasses diets for growing-finishing pigs. 1. Effect on fermentative indices. Nutrition Abstracts and Reviews. $\quad$ v. 50 , p. 590,1986 .

CENCI, G., MOROZZI, G. Evaluation of the toxic effect of $\mathrm{Cd}^{2-}$ and $\mathrm{Cd}(\mathrm{CN})^{2-}$ ions on the growth of mixed microbial population of activated sludges. The Science of the Total Environmental $\vee 7$, p.131-143, 1977. 
CHANEY, R. L. Metal speciation and interation among affect trace elements transfer in agricultural and environmental food chains. In: KRAMER, J. R.; ALLEN, H. E. Metal speciation theory analysis and aplication. Chelsea: Lewis Publication. p.219-260, 1988

COCHRAN, W. G. ; COX, S. M. Experimental designs. New York: Wiley International. 61 lp, 1957.

COKER, E. G.; MATTEWS, P. J. Metals in sewage slude and their potencial effects in agriculture Wather Science Technology. v. 15, p. 209-225, 1983.

COPERSUCAR. Fermentação. São Paulo, 1987. 507p.

CUNNINGHAM, C. M; CARTER, C. M.; MATTIL, K. F. Rupture and protein extraction of petroleum grown yeast. Journal of Food Science. v. 40, p. 732-735, 1975.

DESMONTS, R. Importância do fermento seco na luta da sub-alimentação protéica e a carência vitamínica B. Boletim Informativo Associação Paulista Medicina. v. 8, p.1-11, 1966.

DESMONTS, R. Utilização do levedo na alimentação da criança. Pediatria Prática, v. 39, p. 7-18, 1968.

DREWS, B.; JUST, F.; OLBRICH, H. Absorption of cobalt and manganese by micro-organisms. Brauerei, Vissensch. Beil, v. 3, p. 91-92, 99-103, 1953.

DUNDAS, M. J. ; PAWLUK, S. Heavy metals in cultivated soils and in cereal crops in Alberta. Canadian Journal Soil Science, v. 57, p. 329-339, 1977. 
DZIEDAK, J. D. Yeast and yeast derivatives: definitions, characteristics and processing. Food Technology, v. 41, p. 104, 1987.

EGREJA-FILHO, F. B. Avaliação da ocorrência e distribuição quimica de metais pesados na compostagem de lixo domiciliar urbano. Viçosa, 1993. 176p. Tese (Mestrado). Universidade Federal de Viçosa.

FERGUSON, J. E. Heavy elements: chemistry, environmental impact an healthy effects. New York: Pergamon Press, $1990.614 \mathrm{p}$

FURLETT, M. E .M. Matérias-primas da fermentação etanólica. In: SEMINÁRIO MICROBIOLOGIA DA FERMENTAÇÃO ETANÓlıICA. 1., Rio Claro, 1987. Rio Claro, Universidade Estadual Paulista "Júlio de Mesquita Filho" . p.5-16, 1987.

GADD, G. M. ; GRIFFTHS, A. J. Microorganisms and heavy metal toxicity. Microbiol Ecology, v. 4 , p. $303-317,1978$.

GASPARINI-BARBOSA, N. R. Fermentação etanólica a partir do hidrolisado ácido do bagaço da canade-açúcar, obtido em estágio único, rico em xilose pela levedura Pichia stipilis CBS 5773. Rio Claro, 1995. 125p. Tese (Doutorado). Instituto de Biociências, Universidade Estadual Paulista "Júlio de Mesquita Filho".

HALÁSZ, A. ; LASZTITY, R. Use of yeast biomass in food production. Boca Raton: CRC PRESS $1991,312 \mathrm{p}$.

HANSSEN, J. T. Bioproteins in the feeding of growing-finishing pigs in Norway. I. Chemical composition, nutrient digestibility and protein quality of "Pruteen", "Tropina", "Pequilo" and a methanol-based yeast product (Pichia aganobii). Journal of Animal Physiology and Animal Nutrition. $\vee .47$, p. $35-42,1981$. 
HANSSEN, J. T. Bioproteins in the feeding of growing-finishing pigs in Norway. V. A metanol-based yeast (Pichia aganobii) replacing soyabean meal as protein supplement in cereal diets. Journal of Animal Physiology and Animal Nutrition. v. 47, p. 201-209, 1982.

HENRIKSEN, A. ; WRIGHT, R. F. Concentrations of heavy metals in small Norwegian lakes. Water Ressources Research. v. 12, p. 101-112, 1978.

HERNANDEZ, A. L. Viabilidad celular de Saccharomyces cerevisiae en etapa fermentativa con diferentes concentraciones de cloruro de colina. Santiago de Cali, 1995. 78p.(Trabajo de grado Universidad del Valle).

INSTITUTO CUBANO DE INVESTIGACIONES DE LOS DERIVADOS DE LA CANÃ DE AZÚCAR (ICIDICA) - La Habana - Editorial Científico - Técnica. 1986, 576p.

IVERSON, W. P.; BRINCKMAN, F. E. Microbial metabolism of metals. In: MITCHELL, R. ed Water pollution microbiology, New York: Willey Interscience, 1978. 2v.

JACQUOT, R. Proteínas:um problema alimentar - valor nutritivodas leveduras - sua utilizaçào prática para alimentação humana. Boletim Informativo Associação Paulista de Medicina. v. 8, p. 1-13, 1966.

JORGE, J. A.; CAMARGO, O. A.; VALADARES, J. M. S. A. Condições fisicas de um latossolo vermelho-escuro quatro anos após a aplicação de lodo de esgoto e calcáreo. Revista Brasileira Ciência do Solo. v. 15, p. 237-240, 1991.

KESSELS, B. G. F.; BELDE, P. J. M.; BORST-PAUWELS, G. W. F. H. Protection of Saccharomyces cerevisiae against $\mathrm{Cd}^{2}$ toxicity by $\mathrm{Ca}^{2}$. The Journal of General Microbiology. v. 131, p. 25332537,1985 
KILBERG, R. The microbe as a source of food. Annual Review of Microbiology. v. 26, p. 428-466, 1972 .

KUREK, E.; CZABAN, J,; BOLAG, J. M. Sorption od cadmium by microorganisms in competition with other soil constituints. Applied Envronmental Microbiology. v. 43, p. 1011, 1982.

LIMA, G. J. M. M. Uso da levedura seca (Saccharomyces cerevisiae) de destilarias de álcool de cana-deaçúcar na alimentação de matrizes suinas em gestação e lactação. Piracicaba. 1983. 139p. Tese (Mestrado). Escola Superior de Agricultura "Luiz de Queiroz", Universidade de São Paulo.

LIMA, U. de A. Tecnologia das fermentações, São Paulo: EDUSP, 1975, 285 p (Biotecnologia, 1).

LODDER, J. The yeast: a taxonomic study 2 ed. Amsterdam: North Holland, 1971. 1385p.

LOPES, J. J. C. Bagaço de nutrientes minerais no processo Melle-Boinot de fermentação alcoólica. Piracicaba, 1989. 74p.Tese (Mestrado). Escola Superior de Agricultura "Luiz de Queiroz" , Universidade de São Paulo.

MARQUES, M. S. ; GARCIA, O. Jr. Biohidrometalurgia - Aplicação Industrial e Novas Perspectivas In: First Labs - Latin American Biodeterioration Symposium Campos do Jordão, 1992. Anais. Campos do Jordão, 1992.

MATTIAZO-PREZOTTO, M. M. Comportamento de cobre, cádmio, níquel e zinco adicionados a solos de clima tropical em diferentes valores de pH. Piracicaba, 1994. 197p. Tese (Livre Docência). Escola Superior de Agricultura "Luiz de Queiroz" , Universidade de São Paulo.

MATTOS, W. R. S.; D'ARCE, R. D.; MACHADO, P. F. O uso de levedura da fermentação alcoólica na alimentação de ruminantes. Informe Agropecuário. v. 10, p. 56-60, 1984. 
MEHRISHI, J. N., WIOLAND, M. Eletrokinetic charge approuch for probing events at the membrane level os single viable cells In: LAMBERT P. P. S. et al (eds). The Pathogenicity of cationic proteins. New York: Raven Pres, 1983. p.41-54.

MENTEN, J. F. M.; LIMA, G. J. M. M.; PACKER, I. U; MIYADA, V. S.; LAVORENTI, A. Niveis de uréia e ácido úrico no sangue de porcas alimentadas com rações contendo levedura seca.In: REUNIÃO ANUAL DA SOCIEDADE BRASILEIRA DE ZOOTECNIA. 21, Belo Horizonte, 1984. Anais. Belo Horizonte, SBZ, 1984. 204 p.

MIYADA, V. S. Uso de levedura seca (Saccharomyces cerevisiae) de destilarias de álcool de cana-de açúcar na alimentação de suínos em crescimento e acabamento. Piracicaba. 1978 106p. Tese (Mestrado). Escola Superior de Agricultura "Luiz de Queiroz", Universidade de São Paulo.

MOAT, A. G., FOSTER, J. W. Microbial phisiology. A Willey - Interscience Publication, John Wiley \& Sons. 1988. 597p.

MOREIRA, J. R. A. Uso da levedura seca (Saccharomyces cerevisiae) de destilarias de álcool de canade-açúcar em rações isocalóricas para suinos em crescimento e acabamento. Piracicaba. 1984. 107p. Tese (Mestrado). Escola Superior de Agricultura "Luiz de Queiroz", Universidade de São Paulo.

NAKAJIMA, A; SAKAGUCHI, T. Seletive accummulation of heavy metals by microorganisms Applied Microbiology and Biotechnology. v. 24, p. 24-59, 1986.

NOGUEIRA, A. V. Eficiência agronômica como fertilizante de um lodo de esgoto e de dois resíduos provenientes de indústrias siderúrgicas. Viçosa. 1990. 85 p. Tese (Mestrado). Universidade Federal de Viçosa. 
NORRIS, P. R; KELLY, D. P. Acumulation of cadmiun and cobalt by Saccharomyces cerevisiae. Journal General Microbiology. v. 99, p. 317-324, 1979.

OLBRICH, H. O melaço; sua importância e emprego, com especial referência à fermentação e à fabricação de levedura. 3 ed. Trad. de A. Serzedelo. Rio de Janeiro: IAA, 1960, 150p.

OLIVEIRA, F. C. Metais pesados e formas nitrogenadas em solos tratados com lodo de esgoto. Piracicaba, 1995. 90p. Tese (Mestrado). Escola Superior de Agricultura "Luiz de Queiroz" , Universidade de São Paulo.

OMAE, S. Adsorção e deslocamento de metais pesados cromo, chumbo e cádmio em alguns solos do Estado de São Paulo. Piracicaba, 1986. 170p. Tese (Doutorado). Escola Superior de Agricultura "Luiz de Queiroz", Universidade de São Paulo.

PAYNE, J. H. Operações Unitárias na produção de açúcar de cana - São Paulo: Nobel/STAB, $1989,245 \mathrm{p}$.

PEARSON, R. G. Hard and soft acids and bases. Surving Program Chemycals, v. 5, p. 1, 1969.

PEZZATO, A. C. Utilização de levedura na alimentação de monogástricos: I. Aves In: SEMANA DE ZOOTECNIA, 6; SIMPÓSIO SOBRE APROVEITAMENTO DE SUB-PRODUTOS DA AGROINDÚstria NA ALIMENTAÇÃO ANIMAL, 1., Botucatu, 1985. Anais. Botucatu, 1985. p. $37-55$.

PHAFF, H.; MILLER, M. W; MIRAK, E. M. The life of yeast. London: Harvard University Press. 1978. $341 \mathrm{p}$. 
PINOTTI, R. F. Produção de bagaço de cana, levedura e vinhaça nas usinas de açúcar e álcool. In SENAMA DE ZOOTECNIA,6.; SIMPÓSIO SOBRE APROVEITAMENTO DE SUB-PRODUTOS DA AGROINDÚSTRIA NA ALIMENTAÇÃO ANIMAL, 1, Botucatu, 1985. Anais. Botucatu, 1985. p. 01-22.

PRESCOTT, S. C. ; DUNN, C. G. Industrial Microbiology. 30 ed. New York: McGraw-Hill, 1972. p.60-101.

REMACLE, J. The removal of heavy metals from industrial effluents in a biological fluidised bed. Environmental Technology Letters. v. 4, p. 53, 1990

RODRIGUES, A. J; SILVEIRA, J. J. N.; VELOSO, L.; BONILHA, N.; BACKER, M. Valor da Tórula e da Crisálida na alimentação de suinos. Boletim da Indústria Animal. v. 25, p. 75-80, 1968.

ROSE, A. H. in: Biology and activities of yeast. London: Academic Press, p. 103, 1980.

SALES, A. M.; MENEZES, T. J. B.; OKADA, M.; ARAKAKI, T.; LAMO, P. R. Produção e avaliação nutricional de biomassa protéica de levedura em melaço. Coletânea do Instituto de Tecnologia de Alimentos. v. 8, p. 443, 1977

SERRA, G.; SOUZA, L. G. de; MISCHAN, M. M. Variação sazonal na composição de melaços durante a safra: Brasil Açucareiro. v. 99, n. 1, p. 60-69, Janeiro. 1982.

SHARF, J. M. Exame microbiológico de alimento. 2 ed. São Paulo: Poligono. 1972, 257p.

SILVA, D. J. Análise de alimentos (métodos químicos e biológicos). Viçosa: Universidade Federal de Viçosa/Imprensa Universitária, 1990. 165p 
SIMKISS, K.; TAYLOR, M. G. Metal fluxes across the membranes of aquatic organisms. Critical Reviews in Aquatic Sciences. v 1, p 173-188, 1989.

TILBURY, R. H.; SKINNER, F. A.; PASSMORE, S. M.; DAVENPORT, R. R. Xerotolerant (osmophilie) Yeast. In: Biology and A. Activities of Yeast. London: Academic Press., 1980.

TOBIN, J.; COOPER, D. G.; NEUFELD, R. J. Uptake of metal ions by Rhizopus arrhizus biomass. Applied Environmental Science Technology. v. 6, p. 58, 1972.

TREVORS, J. T; STRATTON, G. W; GADD, G. M. Cadmium transport, resistance and toxicity in bacteria, algae and fungi. Canadian Journal of Microbiology. v. 32, p. 447-464, 1986.

TRINDADE, R. de C.. Adsorção de azo corantes crisoidina CI 11270 e amaranto CI 16185 por células de leveduras do gênero Rhodotorula: Influência de alguns componentes celulares e temperatura. Rio Claro. 1987. 48p. Tese (Mestrado). Instituto de Biociências, Universidade Estadual Paulista.

TYLER, G. Bryophites and heavy metals: a literature review. Botanic Journal of Linnean Society. $v$ 101, p 221-235, 1990.

VANANUVAT, P. Value of yeast protein for poultry feeds. Critical Review and Food Science Nutrition. v. 9, p. 325-343, 1977.

VOLESKY, B. Biosorption and biosorbents In: Volesky, B. (Ed) Biosorption of heavy metals. Boca Raton: CRC Press, 1990, 390p. 
WOOD, J. M. Biological cycles for toxic elements in the environment. Science, v. 183, p. 1049-1052, 1974.

WOOD, J. M; WANG, H. K. Microbial resistance to heavy metals. Environmental Science Technology. v. 17, p. 582-590, 1983.

ZONTA, E. P.; MACHADO, A. A. Sanest 2, Sistema de análise estatística para microcomputadores. Piracicaba: SEI, 1992 (Softer). 
APÊNDICE 1

UNIVERSIDADE DE SÃO PAULO - Campus de Piracicaba

C I A G R I - Centro de informática na Agricultura LATICE QUADRADO

Análise de Variância da Variável $===>$ cádmio

\begin{tabular}{lccccc}
\hline \multicolumn{1}{c}{ Causa da variação } & GL & SQ & QM & F (apr.) & NMS \\
\hline Repetições & 3 & 0.00142989 & 0.00047663 & & \\
Tratamentos (n. aj.) & 8 & 15.29945422 & 1.91243178 & $9528.19^{* *}$ & 0.000 \\
Tratamentos(aj.) $^{*}$ & 8 & 15.29945422 & 1.91243178 & $8053.13^{* *}$ & 0.000 \\
Blocos (aj.) & 8 & 0.00101748 & 0.00012719 & & \\
Erro interbloco & 16 & 0.00379963 & 0.00023748 & & \\
\hline Total & 35 & 15.30570122 & & & \\
\hline
\end{tabular}

Ref. COCHRAN W. G. \& COX. G.M.: Experimental Designs

Fator de Ajustamento : $\quad 0.00000$

Erro Efetivo : $\quad 0.00024$

Var da Dif. entre Tratamentos no mesmo bloco (los. Associados): $\quad 0.00012$

Var da Dif. entre Dois Tratamentos em blocos distintos (2os. Associados): $\quad 0.00012$

Variância Media da Dif. entre Dois Tratamentos: 0.00012

Desvio Padrão Médio da Dif. entre Dois Tratamentos: $\quad 0.01090$

Precisão em Relação a Blocos ao Acaso: $\quad 84.52 \%$

Coeficiente de Variação: $1.59 \%$

\begin{tabular}{ccccc}
\hline Tratamento & Total & Total $(\mathrm{aj})$ & Media & Media (aj) \\
\hline 9 & 0.01800 & 0.01800 & 0.00450 & 0.00450 \\
1 & 0.84000 & 0.84000 & 0.21000 & 0.21000 \\
5 & 2.16000 & 2.16000 & 0.54000 & 0.54000 \\
2 & 2.80000 & 2.80000 & 0.70000 & 0.70000 \\
6 & 3.36000 & 3.36000 & 0.84000 & 0.84000 \\
3 & 5.00000 & 5.00000 & 1.25000 & 1.25000 \\
7 & 5.24000 & 5.24000 & 1.31000 & 1.31000 \\
4 & 7.56000 & 7.56000 & 1.89000 & 1.89000 \\
8 & 7.88000 & 7.88000 & 1.97000 & 1.97000 \\
\hline
\end{tabular}

Médias Ajustadas Com Recuperação da Informação Interblocos 


\begin{tabular}{|c|c|c|c|c|c|}
\hline \multicolumn{6}{|c|}{$\begin{array}{c}\text { UNIVERSIDADE DE SÃO PAULO - Campus de Piracicaba } \\
\text { C I A G R I - Centro de informática na Agricultura } \\
\text { LATICE QUADRADO }\end{array}$} \\
\hline \multicolumn{6}{|c|}{ Análise de Variância da Variável $===>$ massa específica } \\
\hline Causa da variação & $\mathrm{GL}$ & SQ & QM & $\mathrm{F}$ (apr.) & NMS \\
\hline Repetições & 3 & 0.00000001874 & 0.00000000625 & & \\
\hline Tratamentos (n. aj.) & 8 & 0.00000125373 & 0.00000015672 & $81.38 * *$ & 0.000 \\
\hline Tratamentos(aj.)* & 8 & 0.00000112397 & 0.00000014050 & $97.45^{* *}$ & 0.000 \\
\hline Blocos (aj.) & 8 & 0.000002315 & 0.00000000289 & & \\
\hline Erro interbloco & 16 & 0.000002307 & 0.00000000144 & & \\
\hline Total & 35 & 0.00000131869 & & & \\
\hline
\end{tabular}

Ref. COCHRAN W. G. \& COX. G.M.: Experimental Designs

$\begin{array}{lll}\text { Fator de Ajustamento } & : & 0.05575 \\ \text { Erro Efetivo } & : & 0.00000\end{array}$

Var da Dif. entre Tratamentos no mesmo bloco (los. Associados): $\quad 0.00000$

Var da Dif. entre Dois Tratamentos em blocos distintos (2os. Associados): $\quad 0.00000$

Variância Media da Dif. entre Dois Tratamentos: 0.00000

Desvio Padrão Médio da Dif. entre Dois Tratamentos: $\quad 0.00003$

Precisão em Relação a Blocos ao Acaso: $\quad 114.43 \%$

Coeficiente de Variação: $0,00 \%$

\begin{tabular}{ccccc}
\hline Tratamento & Total & Total (aj) & Media & Media (aj) \\
\hline 9 & 3.96520 & 3.96514 & 0.99130 & 0.99130 \\
8 & 3.96640 & 3.96637 & 0.99160 & 0.99160 \\
1 & 3.96660 & 3.96662 & 0.99165 & 0.99165 \\
5 & 3.96670 & 3.96672 & 0.99167 & 0.99167 \\
7 & 3.96680 & 3.96683 & 0.99170 & 0.99170 \\
2 & 3.96690 & 3.96688 & 0.99172 & 0.99172 \\
6 & 3.96720 & 3.96723 & 0.99180 & 0.99180 \\
3 & 3.96760 & 3.96759 & 0.99190 & 0.99190 \\
4 & 3.96800 & 3.96801 & 0.99200 & 0.99200 \\
\hline
\end{tabular}

Médias Ajustadas Com Recuperação da Informação Interblocos 
APÊNDICE 3

\begin{tabular}{|c|c|c|c|c|c|}
\hline \multicolumn{6}{|c|}{$\begin{array}{c}\text { UNIVERSIDADE DE SÃO PAULO - Campus de Piracicaba } \\
\text { C I A G R I - Centro de informática na Agricultura } \\
\text { LATICE QUADRADO }\end{array}$} \\
\hline \multicolumn{6}{|c|}{ Análise de Variância da Variável $===>$ células vivas } \\
\hline Causa da variação & GL & SQ & QM & F (apr.) & NMS \\
\hline Repetições & 3 & 0.00354003906 & 0.00118001302 & & \\
\hline Tratamentos (n. aj.) & 8 & 0.00020408630 & 0.00002551079 & $1.27 \mathrm{~ns}$ & 30.564 \\
\hline Tratamentos(aj.)* & 8 & 0.00012871935 & 0.00001608992 & $1.94 \mathrm{~ns}$ & 12.426 \\
\hline Blocos (aj.) & 8 & 0.00035000000 & 0.00004375000 & & \\
\hline Erro interbloco & 16 & 0.00013303604 & 0.00000831475 & & \\
\hline Total & 35 & 0.00422716141 & & & \\
\hline
\end{tabular}

Ref. COCHRAN W. G. \& COX. G.M.: Experimental Designs

Fator de Ajustamento : $\quad 0.08999$

Erro Efetivo : $\quad 0.00001$

Var da Dif. entre Tratamentos no mesmo bloco (los. Associados): $\quad 0.00001$

Var da Dif. entre Dois Tratamentos em blocos distintos (2os. Associados): $\quad 0.00001$

Variância Media da Dif. entre Dois Tratamentos: 0.00001

Desvio Padrão Médio da Dif, entre Dois Tratamentos: $\quad 0.00230$

Precisão em Relação a Blocos ao Acaso: $\quad 190.60 \%$

Coeficiente de Variação: $0,00 \%$

\begin{tabular}{ccccc}
\hline Tratamento & Total & Total (aj) & Media & Media (aj) \\
\hline 2 & 395.79000 & 395.78640 & 98.94750 & 98.94660 \\
8 & 395.79000 & 395.78640 & 98.94750 & 98.94660 \\
7 & 395.78000 & 395.78810 & 98.94500 & 98.94702 \\
4 & 395.79000 & 395.79000 & 98.94750 & 98.94750 \\
6 & 395.79000 & 395.79000 & 98.94750 & 98.94750 \\
1 & 395.80000 & 395.79190 & 98.95000 & 98.94798 \\
3 & 395.79000 & 395.80080 & 98.94750 & 98.95020 \\
9 & 395.81000 & 395.80460 & 98.95250 & 98.95115 \\
5 & 395.81000 & 395.81180 & 98.95250 & 98.95295 \\
\hline
\end{tabular}

Médias Ajustadas Com Recuperação da Informação Interblocos 


\begin{tabular}{|c|c|c|c|c|c|}
\hline \multicolumn{6}{|c|}{$\begin{array}{c}\text { UNIVERSIDADE DE SÃO PAULO - Campus de Piracicaba } \\
\text { C I A GR I - Centro de informática na Agricultura } \\
\text { LATICE QUADRADO }\end{array}$} \\
\hline \multicolumn{6}{|c|}{ Análise de Variância da Variável $===>$ células mortas } \\
\hline Causa da variação & $\mathrm{GL}$ & $\mathrm{SQ}$ & QM & $F($ apr.) & NMS \\
\hline Repetições & 3 & 0.00354166678 & 0.00118055559 & & \\
\hline Tratamentos (n. aj.) & 8 & 0.00020555564 & 0.00002569445 & $1.28 \mathrm{~ns}$ & 30.159 \\
\hline Tratamentos(aj.)* & 8 & 0.00013000016 & 0.00001625002 & $1.54 \mathrm{~ns}$ & 12.165 \\
\hline Blocos (aj.) & 8 & 0.00035000000 & 0.00004375000 & & \\
\hline Erro interbloco & 16 & 0.00013333319 & 0.00000833332 & & \\
\hline Total & 35 & 0.00423055561 & & & \\
\hline
\end{tabular}

Ref. COCHRAN W. G. \& COX. G.M.: Experimental Designs

Fator de Ajustamento : $\quad 0.08995$

Erro Efetivo : $\quad 0.00001$

Var da Dif. entre Tratamentos no mesmo bloco (los. Associados): $\quad 0.00001$

Var da Dif. entre Dois Tratamentos em blocos distintos (20s. Associados): $\quad 0.00001$

Variância Mcdia da Dif. entre Dois Tratamentos: 0.00001

Desvio Padrão Médio da Dif. entre Dois Tratamentos: $\quad 0.00230$

Precisão em Relaçâo a Blocos ao Acaso: $\quad$ 190.31\%

Coeficiente de Variação: $0.27 \%$

\begin{tabular}{ccccc}
\hline Tratamento & Total & Total (aj) & Media & Media (aj) \\
\hline 5 & 4.19000 & 4.18820 & 1.04750 & 1.04750 \\
9 & 4.19000 & 4.19540 & 1.04750 & 1.04885 \\
3 & 4.21000 & 4.19921 & 1.05250 & 1.04980 \\
1 & 4.20000 & 4.20810 & 1.05000 & 1.05202 \\
4 & 4.21000 & 4.21000 & 1.05250 & 1.05250 \\
6 & 4.21000 & 4.21000 & 1.05250 & 1.05250 \\
7 & 4.22000 & 4.21190 & 1.05500 & 1.05298 \\
2 & 4.21000 & 4.21360 & 1.05250 & 1.05340 \\
8 & 4.21000 & 4.21360 & 1.05250 & 1.05340 \\
\hline
\end{tabular}

Médias Ajustadas Com Recuperação da Informação Interblocos 


\begin{tabular}{|c|c|c|c|c|c|}
\hline \multicolumn{6}{|c|}{$\begin{array}{c}\text { UNIVERSIDADE DE SÃO PAULO - Campus de Piracicaba } \\
\text { C I A G R I - Centro de informática na Agricultura } \\
\text { LATICE QUADRADO }\end{array}$} \\
\hline \multicolumn{6}{|c|}{ Análise de Variância da Variável $==\Rightarrow>$ viabilidade de brotos } \\
\hline Causa da variação & GL & SQ & $\overline{Q M}$ & F (apr.) & NMS \\
\hline Repeticões & 3 & 0.61929750443 & 0.20643250148 & & \\
\hline Tratamentos (n. aj.) & 8 & 0.04813671112 & 0.00601708889 & $0.77 \mathrm{~ns}$ & 63.482 \\
\hline Tratamentos(aj.)* & 8 & 0.03641899906 & 0.00455237488 & $1.35 \mathrm{~ns}$ & 28.884 \\
\hline Blocos (aj.) & 8 & 0.13443888873 & 0.01680486109 & & \\
\hline Erro interbloco & 16 & 0.05391274244 & 0.00336954640 & & \\
\hline Total & 35 & 0.85578584671 & & & \\
\hline
\end{tabular}

Ref. COCHRAN W. G. \& COX. G.M.: Experimental Designs

\begin{tabular}{|c|c|c|c|c|}
\hline \multirow{2}{*}{\multicolumn{5}{|c|}{ Fator de Ajustamento : $\quad 0.08883$}} \\
\hline & & & & \\
\hline Erro Efetivo & 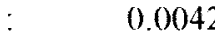 & & & \\
\hline Var da Dif. entre Tra & ntos no mesmo & los. Associado & 00213 & \\
\hline Var da Dif. entre Doi & atamentos em b & stintos (2os. A & 0.002 & \\
\hline Variância Media da I & ntre Dois Trata & 0.00213 & & \\
\hline Destio Padrão Médio & Dif. entre Dois & ntos: & & \\
\hline Precisão em Relação & cos ao Acaso: & $90 \%$ & & \\
\hline Coeficiente de Variag & $0.06 \%$ & & & \\
\hline Tratamento & Total & Total (aj) & Media & Media (aj) \\
\hline 7 & 376.56000 & 376.70746 & 94.14000 & 94.17687 \\
\hline 2 & 376.80000 & 376.72005 & 94.20000 & 94.18001 \\
\hline 8 & 376.80000 & 376.72005 & 94.20000 & 94.18001 \\
\hline 4 & 376.80000 & 376.75558 & 94.20000 & 94.18890 \\
\hline 6 & 376.80000 & 376.75558 & 94.20000 & 94.18890 \\
\hline 1 & 376.91000 & 376.77764 & 94.22750 & 94.19441 \\
\hline 3 & 376.77000 & 376.97343 & 94.19250 & 94.24336 \\
\hline 9 & 377.12000 & 377.04360 & 94.28000 & 94.26090 \\
\hline 5 & 376.98000 & 376.08660 & 94.24500 & 94.27165 \\
\hline
\end{tabular}

Médias Ajustadas Com Recuperação da Informação Interblocos 


\begin{tabular}{|c|c|c|c|c|c|}
\hline \multicolumn{6}{|c|}{$\begin{array}{c}\text { UNIVERSIDADE DE SÃO PAULO - Campus de Piracicaba } \\
\text { C I A G R I - Centro de informática na Agricultura } \\
\text { LATICE QUADRADO }\end{array}$} \\
\hline \multicolumn{6}{|c|}{ Análise de Variância da Variável $===>\%$ brotamento } \\
\hline Causa da variação & GL & SQ & QM & F (apr.) & NMS \\
\hline Repetições & 3 & 53.41666675 & 17.80555558 & & \\
\hline Tratamentos (n. aj.) & 8 & 4.05555558 & 0.50694445 & $0.82 \mathrm{~ns}$ & 59.265 \\
\hline Tratamentos(aj.)* & 8 & 3.34126988 & 0.41765874 & $1.37 \mathrm{~ns}$ & 28.232 \\
\hline Blocos (aj.) & 8 & 9.94444444 & 1.24305556 & & \\
\hline Erro interbloco & 16 & 4.88888881 & 0.30555555 & & \\
\hline Total & 35 & 72.30555558 & & & \\
\hline
\end{tabular}

Ref. COCHRAN W. G. \& COX. G.M.: Experimental Designs

Fator de Ajustamento : $\quad 0.08380$

Erro Efetivo : $\quad 0.38237$

Var da Dif. entre Tratamentos no mesmo bloco (los. Associados): 0.19119

Var da Dif. entre Dois Tratamentos em blocos distintos (20s. Associados): $\quad 0.20399$

Variância Media da Dif. entre Dois Tratamentos: 0.19119

Desvio Padrão Médio da Dif. entre Dois Tratamentos: $\quad 0.43725$

Precisão em Relação a Blocos ao Acaso: $\quad 161.64 \%$

Coeficiente de Variação: $1.13 \%$

\begin{tabular}{ccccc}
\hline Tratamento & Total & Total (aj) & Media & Media (aj) \\
\hline 7 & 193.00000 & 194.17318 & 48.25000 & 48.54330 \\
2 & 195.00000 & 194.32961 & 48.75000 & 48.58240 \\
8 & 195.00000 & 194.32961 & 48.75000 & 48.58240 \\
4 & 195.00000 & 194.66480 & 48.75000 & 48.66620 \\
6 & 195.00000 & 194.66480 & 48.75000 & 48.66620 \\
1 & 196.00000 & 194.91061 & 49.00000 & 48.72765 \\
3 & 195.00000 & 196.67598 & 48.75000 & 49.16899 \\
9 & 198.00000 & 197.41341 & 49.50000 & 49.35335 \\
5 & 197.00000 & 197.83799 & 49.25000 & 49.45950 \\
\hline
\end{tabular}

Médias Ajustadas Com Recuperação da Informação Interblocos 


\begin{tabular}{|c|c|c|c|c|c|}
\hline \multicolumn{6}{|c|}{$\begin{array}{c}\text { UNIVERSIDADE DE SÃO PAULO - Campus de Piracicaba } \\
\text { C I A G R I - Centro de informática na Agricultura } \\
\text { LATICE QUADRADO }\end{array}$} \\
\hline \multicolumn{6}{|c|}{ Análise de Variância da Variável $===>$ peso úmido } \\
\hline Causa da variação & GL & SQ & QM & $\mathrm{F}(\mathrm{apr})$ & NMS \\
\hline Repetições & 3 & 92.4464751 & 30.8154917 & & \\
\hline Tratamentos (n. aj.) & 8 & 60.7783999 & 7.5973000 & $1.52 \mathrm{~ns}$ & 20.392 \\
\hline Tratamentos(aj.)* & 8 & 66.4845621 & 8.3105703 & $3.17 \mathrm{~ns}$ & 2.372 \\
\hline Blocos (aj.) & 8 & 78.3224444 & 9.7903056 & & \\
\hline Erro interbloco & 16 & 41.9881555 & 2.6242597 & & \\
\hline Total & 35 & 273.5354750 & & & \\
\hline
\end{tabular}

Ref. COCHRAN W. G. \& COX. G.M.: Experimental Designs

Fator de Ajustamento : $\quad 0.08133$

Erro Efetivo : $\quad 3.26454$

Var da Dif. entre Tratamentos no mesmo bloco (los. Associados): $\quad 1.63227$

Var da Dif. entre Dois Tratamentos em blocos distintos (2os. Associados): $\quad 1.73898$

Variância Media da Dif. entre Dois Tratamentos: 1.63227

Desvio Padrão Médio da Dif. entre Dois Tratamentos: 1.27760

Precisão em Relação a Blocos ao Acaso: $\quad 153.56 \%$

Coeficiente de Variação: $2.80 \%$

\begin{tabular}{ccccc}
\hline Tratamento & Total & Total (aj) & Media & Media (aj) \\
\hline 4 & 224.42000 & 221.21974 & 56.10500 & 55.30493 \\
5 & 225.07000 & 221.97302 & 56.26750 & 55.49326 \\
6 & 226.98000 & 230.39660 & 56.74500 & 57.59915 \\
8 & 232.89000 & 231.21627 & 58.22250 & 57.80407 \\
1 & 234.19000 & 233.10671 & 58.54750 & 58.27668 \\
3 & 229.72000 & 233.52860 & 57.43000 & 58.38215 \\
7 & 234.78000 & 234.50104 & 58.69500 & 58.62526 \\
9 & 233.47000 & 235.87731 & 58.36750 & 58.96933 \\
2 & 241.71000 & 241.41071 & 60.42750 & 60.35268 \\
\hline
\end{tabular}

Médias Ajustadas Com Recuperação da Informação Interblocos 


\begin{tabular}{|c|c|c|c|c|c|}
\hline \multicolumn{6}{|c|}{$\begin{array}{c}\text { UNIVERSIDADE DE SÃO PAULO - Campus de Piracicaba } \\
\text { C I A G R I - Centro de informática na Agricultura } \\
\text { LATICE QUADRADO }\end{array}$} \\
\hline \multicolumn{6}{|c|}{ Análise de Variância da Variável $===>$ proteína bruta } \\
\hline Causa da variação & GL & SQ & QM & F (apr.) & NMS \\
\hline Repetições & 3 & 20.8852558 & 6.9617519 & & \\
\hline Tratamentos (n. aj.) & 8 & 60.3422391 & 7.5427799 & $0.66 \mathrm{~ns}$ & 72.080 \\
\hline Tratamentos(aj.)* & 8 & 86.4144042 & 10.8018005 & $1.75 \mathrm{~ns}$ & 16.255 \\
\hline Blocos (aj.) & 8 & 175.5159093 & 21.9394887 & & \\
\hline Erro interbloco & 16 & 98.8583850 & 6.1786491 & & \\
\hline Total & 35 & 355.6017891 & & & \\
\hline
\end{tabular}

Ref. COCHRAN W. G. \& COX. G.M.: Experimental Designs

Fator de Ajustamento

Erro Efetivo

0.07982

7.65818

Var da Dif. entre Tratamentos no mesmo bloco (los. Associados): 3.82909

Var da Dif. entre Dois Tratamentos em blocos distintos (2os. Associados): $\quad 4.07568$

Variância Media da Dif. entre Dois Tratamentos: 3.82909

Desvio Padrão Médio da Dif. entre Dois Tratamentos: 1.95681

Precisão em Relação a Blocos ao Acaso: $\quad 149.28 \%$

Coeficiente de Variação: $6.84 \%$

\begin{tabular}{ccccc}
\hline Tratamento & Total & Total (aj) & Media & Media (aj) \\
\hline 6 & 137.08000 & 132.86392 & 34.27000 & 33.21598 \\
9 & 141.19000 & 138.23268 & 35.29750 & 34.55817 \\
8 & 140.65000 & 139.75362 & 35.16250 & 34.93841 \\
7 & 142.98000 & 143.09813 & 35.74500 & 35.77453 \\
4 & 145.29000 & 147.46509 & 36.32250 & 36.86627 \\
2 & 148.80000 & 148.38334 & 37.20000 & 37.09584 \\
5 & 155.27000 & 150.28526 & 38.81750 & 37.57131 \\
3 & 148.41000 & 153.22233 & 37.10250 & 38.30558 \\
1 & 148.23000 & 154.59562 & 37.05750 & 38.64891 \\
\hline
\end{tabular}

Médias Ajustadas Com Recuperação da Informação Interblocos 


\begin{tabular}{|c|c|c|c|c|c|}
\hline \multicolumn{6}{|c|}{$\begin{array}{c}\text { UNIVERSIDADE DE SÃO PAULO - Campus de Piracicaba } \\
\text { C I A G R I - Centro de informática na Agricultura } \\
\text { LATICE QUADRADO }\end{array}$} \\
\hline \multicolumn{6}{|c|}{ Análise de Variância da Variável $==\equiv$ \% nitrogênio } \\
\hline Causa da variação & GL & SQ & QM & $\mathrm{F}$ (apr.) & NMS \\
\hline Repetições & 3 & 0.5176277776 & 0.172542592 & & \\
\hline Tratamentos (n. aj.) & 8 & 1.525457498 & 0.190682187 & $0.65 \mathrm{~ns}$ & 72.729 \\
\hline Tratamentos(aj.)* & 8 & 2.167107993 & 0.270888499 & $1.69 \mathrm{~ns}$ & 17.777 \\
\hline Blocos (aj.) & 8 & 4.451987018 & 0.556498377 & & \\
\hline Erro interbloco & 16 & 2.570135702 & 0.160633481 & & \\
\hline Total & 35 & 9.065207992 & & & \\
\hline
\end{tabular}

Ref. COCHRAN W. G. \& COX. G.M.: Experimental Designs

Fator de Ajustamento : $\quad 0.07904$

Erro Efetivo : $\quad 0.19872$

Var da Dif. entre Tratamentos no mesmo bloco (los. Associados): $\quad 0.09936$

Var da Dif. entre Dois Tratamentos em blocos distintos (2os. Associados): 0.10571

Variância Media da Dif. entre Dois Tratamentos: 0.09936

Desvio Padrão Médio da Dif. entre Dois Tratamentos: 0.31522

Precisão em Relação a Blocos ao Acaso: $\quad 147.23 \%$

Coeficiente de Variação: $6.90 \%$

\begin{tabular}{ccccc}
\hline Tratamento & Total & Total $($ aj) & Media & Media (aj) \\
\hline 6 & 21.93200 & 21.25669 & 5.48300 & 5.31417 \\
9 & 22.59000 & 22.11434 & 5.64750 & 5.52859 \\
8 & 22.50400 & 22.35477 & 5.62600 & 5.58869 \\
7 & 22.87600 & 22.91552 & 5.71900 & 5.72888 \\
4 & 23.24700 & 23.58442 & 5.81175 & 5.89610 \\
2 & 23.80800 & 23.73465 & 5.95200 & 5.93366 \\
5 & 24.84400 & 24.07511 & 6.21100 & 6.01878 \\
3 & 23.65500 & 23.41796 & 5.91375 & 6.10449 \\
1 & 23.71600 & 24.71853 & 5.92900 & 6.17963 \\
\hline
\end{tabular}

Médias Ajustadas Com Recuperação da Informação Interblocos 